\title{
Ptychopariid trilobites in the Middle Cambrian of Central Bohemia (taxonomy, biostratigraphy, synecology)
}

\author{
VRATISLAV KORDULE
}

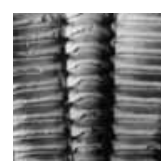

\begin{abstract}
A revision of ptychopariid trilobites from the Middle Cambrian of central Bohemia is presented. With a few exceptions, they were previously referred only to Ptychoparia striata. Three genera are recently distinguished: Ptychoparia Hawle \& Corda, 1847, Ptychoparioides Růžička, 1940, and Mikaparia gen. nov. Seven species are described: three are revised, four are new, and two is left in open nomenclature; their stratigraphical ranges and significance are discussed. A new stratigraphical subdivision of the Middle Cambrian of the Skryje-Týrovice area is suggested, including three assemblage zones and three barren zones. Four substrate and bathymetrically controlled trilobite associations are recognized in the Skryje-Týřovice area. • Key words: Bohemia, Middle Cambrian, trilobites, new taxa, biostratigraphy.
\end{abstract}

Kordule, V. 2006. Ptychopariid trilobites in the Middle Cambrian of Central Bohemia (taxonomy, biostratigraphy, synecology). Bulletin of Geosciences 81(4), 277-304 (13 figures). Czech Geological Survey, Prague. ISSN 1214-1119. Manuscript received February 17, 2005; accepted in revised form December 4, 2006; issued December 31, 2006.

Vratislav Kordule, Dlouhá 104, 26101 Příbram III, Czech Republic; Vkordule@seznam.cz

Representatives of the genera Ptychoparia Hawle \& Corda 1847, Ptychoparioides Růžička, 1940, and Mikaparia gen. nov. are significant components of the trilobite fauna of the Middle Cambrian marine deposits in the Jince and Skryje-Týrrovice areas. Specimens referred to these taxa were already described in part by Emmrich (1839), but a modern revision has appeared necessary since the paper of Šnajdr (1958). It is apparent that some formerly described ptychopariid species constitute so-called "cumulative" taxa.

Several authors have studied this trilobite group on material from Central Bohemia. The earliest detailed study by Barrande (1852) was followed by the contributions of Pompeckj (1896), Jaekel (1901), Růžička (1940, 1944), Richter (1940), and Šnajdr (1958, 1982). Růžička (1940) described several new genera and species from the basal Mileč Sandstone from the Na Kamenných hůrkách locality near Týřovice in the Skryje-Týřovice area. However, the majority of these species has been based on tectonically deformed specimens. Richter (1940) and Šnajdr (1958) critically evaluated this article. Both authors referred all of Růžicka's species to the genus Ptychoparia and to the species Ptychoparia striata (Emmrich, 1839). A new study of the original and new material confirmed the validity of some taxa described by Rủžička (1940, 1944), primarily of the genus Ptychoparioides Růžička, 1940. Vokáč (1997) also studied ptychopariids, but there are some uncertainties in his systematic. Although the present author was unable to study the materials in Vokáč's private collection, the specimens described and figured by Vokáč (1997) can be identified, and their taxonomic position is revised.

Following the previous stratigraphical models (their summary is given in Havlíček 1998 and Fatka et al. 2004, Fatka 2006), Fatka \& Kordule (1992), and Kordule (1996), presented a detail biostratigraphical scheme for the Middle Cambrian of the Jince area, based on distribution of index trilobites. A similarly detailed stratigraphy of the Middle Cambrian in the Skryje-Týřovice is missing. Stratigraphical schemes of the Middle Cambrian of the Skryje-Týřvice have been presented by Kettner (1923), and refined by Šnajdr (1958) and Havlíček $(1971,1998)$, but all are too general. The taxonomical revision of ptychopariid species with a compilation of their distributive data allows some corrections and additions to actual stratigraphic subdivision of the Middle Cambrian in the Skryje-Týrovice area; some ptychopariids are the valuable index species.

\section{Material and methods}

The specimens of studied collections are preserved in a variety of rock types, from coarse-grained quarzitic sandstone, greywacke, de-calcified siltstone, mudstone to carbonatic nodules. Some specimens from fine-grained sediments show minute details (tubercles, genal caeca) that are absent in those coming from coarse-grained rocks. 
Most of the specimens are slightly tectonically distorted; therefore the biometrical data are employed with a caution.

Locality names are consistent with names used by Šnajdr (1958; pp. 25-29) and Fatka \& Kordule (1992). All figured specimens are covered by ammonium chloride if not otherwise stated.

Abbreviation of the collections: NM - Palaeontological collections of the National Museum, Prague; ČGÚ MŠ Palaeontological collection of M. Šnajdr stored in the Czech Geological Survey, Prague; ČGÚ VK - Author's collection stored in the Czech Geological Survey, Prague; C̆GÚ XB - Palaeontological collection of the Czech Geological Survey, Prague.

\section{Systematic part}

Superfamily Ptychopariacea Matthew, 1887

Family Ptychopariidae Matthew, 1887

Subfamily Ptychopariinae Matthew, 1887

\section{Genus Ptychoparia Hawle \& Corda, 1847}

Type species. - Conocephalus striatus Emmrich, 1839; Middle Cambrian, Bohemia, Czech Republic.

Emended diagnosis (Šnajdr 1958). - Glabella tapering forward, with weakly rounded anterior; four pairs of glabellar furrows; cephalic border prominent, rather long (sag.); anterior border furrow deep; genal spine prominent, short, rapidly tapering, extending backward toward the third segment; genal caeca prominent on external surface of preglabellar field, preocular field of fixigenae and librigenal field of librigenae; pygidium with 5 to 6 axial rings and terminal piece; pleural lobes with distinct pleural and interpleural furrows; exoskeleton surface with finely tuberculate sculpture.

Discussion. - E. \& R. Richter (1941, p. 53) selected Ptychoparia sternbergiana Boeck, 1827 as the type species. However, this species is considered to be a nomen dubium (see Šnajdr 1986, p. 21). Neither the subsequent descriptions of the cranidium and the pygidium given by Šnajdr (1958), nor his generic diagnosis of Ptychoparia are correct because of a mismatch of the features of more than one species. The revised taxonomy therefore requires an emended diagnosis for the genus Ptychoparia.

The most valuable morphological features of the dorsal exoskeleton of Ptychoparia and allied genera that are used for their classification are:

1. the length of cranidium (sag.) relative to the length (sag.) of the anterior border (LCr/LAB index);

2. the morphology of the genal caeca and the sculpture of the cephalon;
3. the morphology of the pleural lobes on the pygidium;

4. the number of pygidial axial rings.

Based on these features, three morphological groups that likely represent particular evolutionary lineages have been distinguished. The first lineage (Ptychoparia Group) comprises several species of Ptychoparia, some of which are rare and insufficiently known. The second lineage $(M i$ kaparia Group) comprises two species. The third lineage (Ptychoparioides Group) comprises three species, although Šnajdr (1958) synonymised Ptychoparioides Růžička, 1940 with Ptychoparia and all species of Ptychoparoides considered invalid. Members of all three lineages have been observed in a substantial part of the Middle Cambrian succession in central Bohemia, and are present both in the Jince and Skryje-Týřovice areas.

By comparing the original and the new specimens it has been observed that the diagnoses of the genus Ptychoparia given by Barrande (1852) and Šnajdr (1958) involved lumping particular species of the Ptychoparia and Mikaparia lineages. Their diagnoses therefore do not reflect the actual morphology of Ptychoparia. Some specimens used in their diagnoses are now grouped into the new genus Mikaparia sp. nov. In addition, new specimens that are comparable with those studied by Růžička (1940) indicate the validity of Agraulopsis resseri, the species referred by Šnajdr (1958) to P. striata; the revision of this species is out of scope of the present paper.

Species included. - Ptychoparia striata (Emmrich, 1839); Middle Cambrian, Bohemia, Czech Republic. Ptychoparia dubinka sp. nov.; Middle Cambrian, Bohemia, Czech Republic. Ptychoparia cf. striata (Emmrich, 1839); Middle Cambrian, Bohemia, Czech Republic. Ptychoparia? sp. A.; Middle Cambrian, Bohemia, Czech Republic.

Ptychoparia striata (Emmrich, 1839) Figures 1A-M, 2J, K

1825 Trilobites Sulzeri var. $\gamma$ - - Sternberg, pl. 2, fig. 1 A.

1839 Conocephalus striatus Emmrich; Emmrich, p. 43.

1847 Ptychoparia striata nob. - Hawle \& Corda, p. 25, pl. 2, fig. 11.

1852 Conocephalites striatus Emmrich. - Barrande (partim), pl. 14, fig. 3, non figs 1, 2, 4-7.

1896 ?Solenopleura spec. - Pompeckj, pl. 15, fig. 21.

1906 Ptychoparia striata Emmrich. - Lorenz, p. 58.

1940 Ptychoparia lobifera Růžička; Růžička, p. 4, pl. 1, figs $10-12$.

1940 Ptychoparia gracilis Růžička; Růžička, p. 4, pl. 1, figs 13-15.

1940 ?Lobocephalus cylindricus Růžička; Růžička, p. 9, pl. 1, fig. 22. 
1940 Ptychoparioides nobilis Růžička; Růžička (partim), p. 5, pl. 2, fig. 5 .

1952 Ptychoparia striata (Emmrich). - Prantl, fig. on p. 261.

1953 Ptychoparia striata (Emmrich, 1839). - Přibyl, p. 62.

1953 Ptychoparia gracilis Růžička. - Přibyl, p. 62.

1958 Ptychoparia striata (Emmrich, 1839). - Šnajdr (partim), p. 185, pl. 38, figs 16, 19, non figs 18, 20; pl. 39, figs 4, 6-7, non figs $1-3,5$; pl. 40, fig. 1 , non figs 2 , 4 , 6-7.

1959 Ptychoparoides Růžička. - Moore (partim), p. 232, fig. 170-8b (non 170-8a).

1970 Ptychoparia striata (Emmrich, 1839). - Horný \& Bastl (partim), pp. 25, 147, 193, 301; non pl. 4, fig. 1 (= Mikaparia milena gen. et sp. nov.).

1983 Ptychoparia striata (Emmrich, 1939). - Šnajdr, p. 196, pl. 3, fig. 2 (= invalid holotype selection by Šnajdr).

1989 Ptychoparia striata (Emmrich, 1939). - Pek \& Vaněk, p. 28.

1989 Ptychoparia lobifera Růžička, 1940. - Pek \& Vaněk, p. 43 (= noted as ?Ptychoparia mutica by Pek \& Vaněk).

1989 Ptychoparia striata. - Prokop, fig. on pl. 5, fig. 2.

1993 Ptychoparia striata (Emmrich). - Levi-Setti, p. 179, pl. 103.

1997 Ptychoparia striata (Emmrich, 1839). - Vokáč, pl. 1, figs 7-9.

2001 Ptychoparia striata (Emmrich, 1839). - Vaněk \& Valíček, p. 6.

Neotype. - Designated and figured by Šnajdr (1958, pl. 38, fig. 19), the complete specimen (catalogue numbers: old number C̆C 330, No. 536; new number L 15177a) selected from the specimens of Barrande's collection stored in the National Museum, Prague, figured herein in Fig. 1B. It comes from material with the same catalogue number for several specimens. This specimen was never figured by Barrande. This explains that later references quoting this specimen as being figured by Barrande (1852, pl. 29, fig. 39) are incorrect, and refer to another specimen with the same catalogue number (ČC 330, No. 536).

The original specimens of Emmrich's collection have been lost. The selection of the holotype by Šnajdr (1983) is invalid because there is no evidence that this specimen comes from Emmrich's original collection. This specimen coming from Hawle's collection (Hawle \& Corda 1847, pl. 2, fig. 11; refigured by Šnajdr, 1983, pl. 3, fig. 2), is almost complete though damaged, and is preserved as the internal mould in shale with the original label attached. This specimen is actually housed in the palaeontological collection of the National Museum, Prague, catalogue number NM L 17634.

Type horizon and locality. - Jince Formation, probably $\mathrm{Pa}$ radoxides gracilis Zone; Czech Republic, Jince, slope cal- led Vinice or Vystrkov Hill (determination based on lithology and mode of preservation).

Material. - Several tens of complete specimens and other parts of exoskeletons, mainly from the Paradoxides gracilis Zone.

Diagnosis. - Ptychoparia with S1, S2 very conspicuous, S3 distinct, S4 poorly marked, S1 unforked; paradoublure line poorly defined; pygidium with five rings and axial piece; pleural fields with four distinct ribs and a weakly defined fifth rib; genal caeca prominent on librigenae and frontal parts of fixigenae.

Emended description: Some new data is added to the descriptions of former authors (Šnajdr 1958). Anterior border is high, robust, highly convex, with maximum length at sagittal axis, tapering abaxially. Average LCr/LAB index is 5 (range $4.5-7$ based on tectonic deformation). Genal spines are of moderate length. The exoskeleton is densely penetrated by fine punctae, including the lateral borders of the hypostome, the frontal part of rostrum and the cephalic doublure. Genal caeca prominent on librigenae and frontal parts of fixigenae. Caeca consist of radial canals essentially normal to lateral and anterior margins of the cephalon. The anastomosing canals are located more anterolaterally. The caecal morphology is clearly impressed on internal surface but only partly distinct on the outer surface of the cephalon. The fine tubercles cover bottom of interspaces between the caecal canals. The pygidial axis bears five distinct axial rings and the terminal piece. Pleural fields with four distinct ribs, fifth rib developed as weak elevation near the terminal axial piece. Pleural and interpleural furrows clearly differentiated.

The common length of a complete exoskeleton is $50 \mathrm{~mm}$, rarely attaining nearly $70 \mathrm{~mm}$.

Remarks. - The most accurate description of this species was presented Šnajdr (1958, pp. 185-190). However, this author used several different taxa in his general description, which must therefore be revised. The cephalon figured by Šnajdr (1958, p. 187, pl. 40) and referred to Ptychoparia striata (Emmrich) belongs to Mikaparia milena sp. nov. This cephalon has LCr/LAB of about 10 (anterior border is sagittally very short). Also the specimen figured by Barrande (1852) and refigured Moore et al. (1959, fig. $170: 6$ on p. O232) as $P$. striata is actually M. milena. The pygidium figured by Šnajdr (1958, Fig. 41) bears six axial rings and a terminal piece, and shows a distinct differentiation of the pleural and interpleural furrows; it actually belongs to Ptychoparia dubinka sp. nov.

Remains of soft and weakly sclerotised parts have been observed in several new specimens. Similar structures were made known by Jaekel (1901) from the closely related species $P$. dubinka sp. nov. However, Šnajdr (1958) 
expressed doubt about the origin of these impressions. Description of these soft and weakly sklerotised parts will be published elsewhere.

The earliest occurrence of $P$. striata is known from the basal sandstone of the Mileč Formation in the Skryje-Týrovice area. The species Ptychoparia lobifera and P. gracilis, both described as new taxa by Růžička (1940) from the Mileč Formation, were synonymized with P. striata by Šnajdr (1958). Newly discovered pygidia with five axial rings and the terminal piece support this opinion. The early specimens of $P$. striata from the Skryje-Týrovice area support the assumption that the species appeared in the Jince area slightly later, as the earliest and rare remains of the species are known from the Acadolenus snajdri Subzone. The species reached its maximum abundance in the Paradoxides gracilis Zone. All known complete exoskeletons of the species come from this zone.

Barrande (1852) presented the first description of P. striata. He described in detail the morphology of exoskeletons and evaluated the opinions of former authors. Pompeckj (1896) and Růžička (1940) included all now distinguished species of this genus in P. striata. In addition, Šnajdr (1958) used specimens from various stratigraphic levels of the Skryje-Týřovice and Jince areas in his redescription. However, the specimens referred by him to $P$. striata are now considered as particular species of three separate genera. Contrary to the synonymy list published by Šnajdr (1958), the following taxa are considered to be valid: Conocoryphe mutica Hawle \& Corda, 1847, Solenopleura torifrons Pompeckj, 1896, and Agraulopsis resseri Růžička, 1940.

Several complete specimens figured by Barrande (1852) and Šnajdr (1958) from the Paradoxides gracilis Zone do not belong to the Ptychoparia Group. They are referred here to Mikaparia milena gen. and sp. nov. Both Richter (1940) and Šnajdr (1958) referred Agraulopsis resseri Růžička, 1940 to $P$. striata, as they believed that the original material represented extremely deformed individuals. Vokáč (1997) expressed some doubts about the type specimen selection of Šnajdr (1983).

This author preferred the type specimen of Ptychoparia striata that Šnajdr (1958) selected from the Barrande's collection. Because all original specimens of Emmrich's
(1839) collection have been misplaced among other specimens or were lost, it is wholly impossible to identify the original type specimen. In his description of $P$. striata, Barrande (1852) used the specimens from two genera, namely from the species Ptychoparia striata (Emmrich) and Mikaparia milena gen. et sp. nov. In addition, the neotype selected by Šnajdr (1958, pl. 38, fig. 19) had never been figured earlier, despite the mistaken claims of other authors (Vokáč 1997, Vaněk \&Valíček 2001) that it had been figured by Barrande (1852). This specimen has the same catalogue number as several unfigured specimens from Barrande's collection. Such ambiguity probably led Šnajdr (1983) to select the new type specimen (holotype by monotypy) from the Hawle's collection, because this specimen is the earliest collected, described, figured, and hitherto preserved specimen of $P$. striata. It is probable that this specimen originates from the same locality as Emmrich's specimen. It is noteworthy to add that the neotype by Šnajdr (1958) and the more recently chosen holotype (Šnajdr 1983) belong to the same species. Moreover, Šnajdr's (1983) selection is consistent with the original description of Emmrich (1839), as well as the later description by Barrande (1852). The subsequent selection of the supposed holotype by Šnajdr (1983) is invalid.

Occurrence. - Skryje-Týřovice area: basal conglomerates and sandstones of the Mileč Formation; localities Malá Pleš near Kouřimecká hájovna, Na Kamenných hůrkách near Týřovice, Mileč Hill, and Slapnický mlýn. Jince Formation, Týřovice Greywackes, localities Hlohovice, and Čilá (new locality "U tří chat").

Jince area: Jince Formation; in all localities from the Acadolenus snajdri Subzone to Paradoxides gracilis Zone.

\section{Ptychoparia dubinka sp. nov.}

Figures 2A-I, 3A-F

1896 Ptychoparia striata Emmr. sp. - Pompeckj, pp. 541, 542, pl. 17, figs 6-8.

1901 Ptychoparia striata Emm. sp. - Jaekel, pp. 133, 136-138, pls 4-6.

1941 Ptychoparia striata (Emmrich). - Prantl, p. 118.

Figure 1. Ptychoparia striata (Emmrich, 1839). Jince Formation, probably Paradoxides gracilis Zone (A, B), Paradoxides gracilis Zone (C, D, F, G, M), Interval zone between Eccaparadoxides pusillus Zone and Paradoxides gracilis Zone (E), Mileč Formation (H-J). Localities: Jince, exact locality unknown (A, B), Jince, Vystrkov Hill (C, E, G), Jince, slope called Vinice (D, F, M), Skryje, Slapnický mlýn (K, L), Malá Pleš Hill near Kouřimecká myslivna (H-J). • A - complete small specimen, internal mould, NM L 17634, × 1.6 (designated as holotype by Šnajdr 1983). B - complete specimen, internal mould, NM L 15177a, × 1.2 chosen by Šnajdr (1958) as neotype. • C - cephalon with part of thorax, internal mould, ČGÚ VK $215, \times 1.4$. $\bullet$ D - hypostom, internal mould, ČGÚ VK $216, \times 3.1$ • E - pygidium, internal mould, ČGÚ VK $217, \times 2.5$. $\bullet$ F - incomplete specimen with hypostome in situ, internal mould, C̆GÚ VK 218, × 1.9. • G - laterodorsal view of cephalon with free cheek, internal mould, C̆GÚ VK 215, × 1.7. • H - free cheek, internal mould, ČGÚ VK 219, × 2.8. • I - incomplete cranidium, internal mould, ČGÚ VK 220, × 3.0. • J - incomplete cranidium, internal mould, ČGÚ VK $221, \times 1.4$. $\mathrm{K}, \mathrm{L}-$ incomplete cranidium, internal mould, and its oblique view, MŠ $9770, \times 2.7, \times 2.7$. $\bullet$ M - incomplete specimen showing sediment infilling of a gut, internal mould, NM L $6104, \times 1.7$. 
Vratislav Kordule - Ptychopariid trilobites in the Middle Cambrian of Bohemia
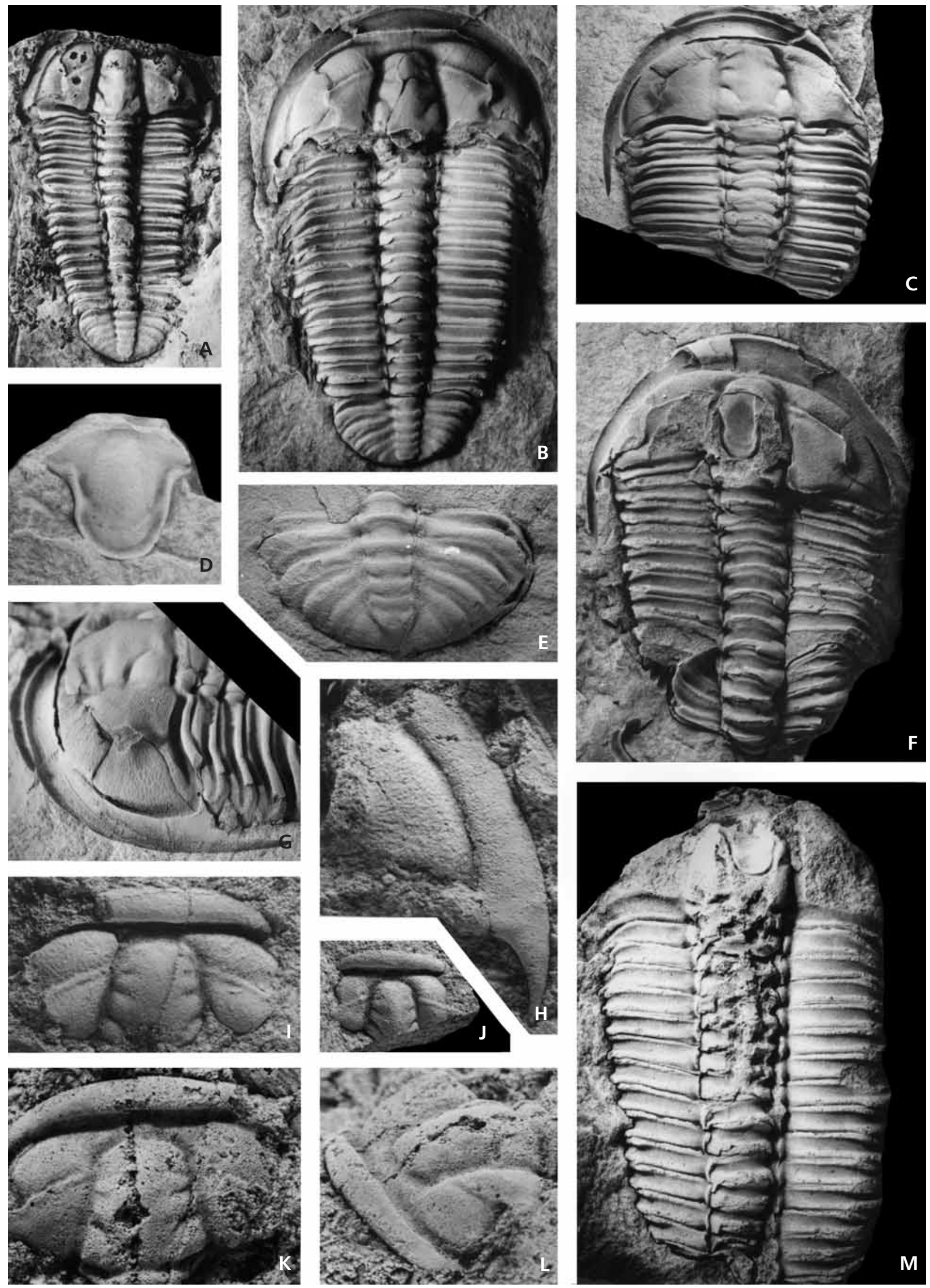
1958 Ptychoparia striata (Emmrich, 1839). - Šnajdr (partim), pp. 185, 189, text-fig. 41, pl. 39, fig. 3 .

1997 Ptychoparia tenuis Pompeckj. - Vokáč, p. 16 (partim), pl. 1, figs 2-4, non fig. 5 (= Mikaparia mutica).

1999 Ptychoparia dubinka sp. n. - Kordule, p. 18 (nomen nudum).

Holotype. - Pygidium preserved as internal mould in siltstone, figured in Fig. 2E, housed in the collections of the Czech Geological Survey, Prague (ČGÚ VK 225).

Derivation of name. - After Dubinky Hill near Skryje.

Type horizon and locality. - Jince Formation, Skryje Shale, lower part of Eccaparadoxides pusillus Zone; Czech Republic, Skryje, hillside of Dubinky Hill in Zbiroh Creek valley (2.5 km SW of Skryje).

Material. - Several hundred complete specimens from a sandstone intercalation at the Pod trním locality near Týřovice, and several tens of cranidia, pygidia, librigenae, hypostomes from other localities in Skryje-Týřovice area.

Diagnosis. - Ptychoparia with S1, S2, S3 and S4 deeply incised and clearly defined; adaxial portion of S1 forked; anterior border prominent, with average $\mathrm{LCr} / \mathrm{LAB}$ cca 6.0; genal caeca with anastomosing canals very prominent in external surface of the cephalon; paradoublural furrow distinctly separated from border furrow; distal ends of pleurae extended into short spines in all segments; pygidial axis with six axial rings and terminal piece; pygidial pleural fields with five pairs of ribs and rudimentary sixth rib; exoskeleton generally larger than in P. striata.

Description. - Dorsal exoskeleton heteropygous, elongately oval in outline, generally $70 \mathrm{~mm}$ in length, but might reach $100 \mathrm{~mm}$ as maximum. Cephalon broadly semicircular, less convex adaxial than abaxial periphery. Genal angle with prominent, although rapidly tapering genal spines that extend backward to approximately fifth thoracic segment. Glabella trapezoidal, tapering forward, weakly rounded anteriorly, defined by deep and wide axial and preglabellar furrows. Glabella bears four pairs of glabellar furrows. S1 longest, oblique, strongly curved backward, forked adaxially, with weaker and shallower anterior branch. S2, S3 are shorter and shallower; S2 curved backward, S3 almost normal to sagittal axis; S4 very short, transverse, weekly impressed anterior to ocular ridge. Occipital ring highly vaulted with small median node. Occipital furrow deeper abaxially, with shallow axial portion arched forward. Preglabelar field long, moderately vaulted. Anterior border strongly convex, long, with LCr/LAB cca 6.0, rapidly tapering abaxially. Anterior border furrow deep and wide (sag.), paradoublure furrow well defined in front of pregla- bellar furrow and adjacent part of fixigenae. Fixigena as wide (tr.) as glabella, gently convex (exsag.). Palpebral lobe of moderate size, feebly convex, situated opposite to $\mathrm{S} 1$, weakly raised above surface of fixigena. Ocular ridge prominent, inclined backward, slightly curved, uniting palpebral lobe with axial furrow slightly behind to S4. Librigena subtriangular in general outline, gently vaulted (exsag.), with evenly wide (tr.) border and narrow and shallow border furrow. Facial sutures differentiated; $\alpha-\beta$ convex adaxially, $\beta-\gamma$ convergent, and $\varepsilon-\omega$ divergent to the genal angle. Preocular area of fixigena and librigena as well as preglabellar area covered by distinct, anastomosing ridges of genal caeca in chevron-like arrangement. Postocular fixigena with similar but much finer and less regular ridges.

Hypostome with prominent anterior lobe, distinct and much shorter posterior lobe separated by distinct middle furrow. Borders highly raised laterally and posteriorly. Anterior margin almost flat and weakly differentiated from anterior lobe. Dorsal surface of exoskeleton densely covered by fine hollow tubercles.

Long thorax of fourteen segments gently tapering backward. Axis strongly vaulted (tr.), almost evenly broad (tr.) along whole length, well defined by deep axial furrows. Pleurae fulcrate, with horizontal proximal and steeply sloping distal parts. Pleural furrow broad, concave (exsag.) tapering and deepening toward pleural tip. Anterior pleural band narrower than posterior band, which is gently expanding abaxially. Pleural extremities shortly pointed, gradually extending in posterior segments, with long, almost backward-directed spines.

Pygidium semicircular, gently vaulted. Pygidial axis long, highly convex, with six rings and terminal subtriangular piece. Lateral lobes with five distinct ribs on each pleural field and weakly defined sixth rib. Ribs separated by deep pleural furrows distinct toward very narrow (exsag.) and steeply sloping border. Interpleural furrows shallower than pleural furrows, but well defined and distinct all the way to the border. The pygidial doublure is narrow, gently extending anterolaterally.

External surface of exoskeleton densely covered by minute uniformly sized tubercles.

Remarks. - Vokáč (1997) suggested that Ptychoparia striata tenuis Pompeckj, 1896 is a valid taxon. However, the type specimen belongs to Mikaparia mutica (Hawle \& Corda, 1847) and remains a subjective synonym. This corrected attribution is based on $\mathrm{LCr} / \mathrm{LAB}$, which is cca 9.5. As evident from his synonymy list and illustrations, Vokáč (1997) confused two different species: Ptychoparia dubinka sp. nov. and Mikaparia mutica (Hawle \& Corda, 1847). In addition, Vokáč (1997) referred Ptychoparia mutica to the genus Conocoryphe, although shapes of the pygidia of Mikaparia and Conocoryphe are quite different. 

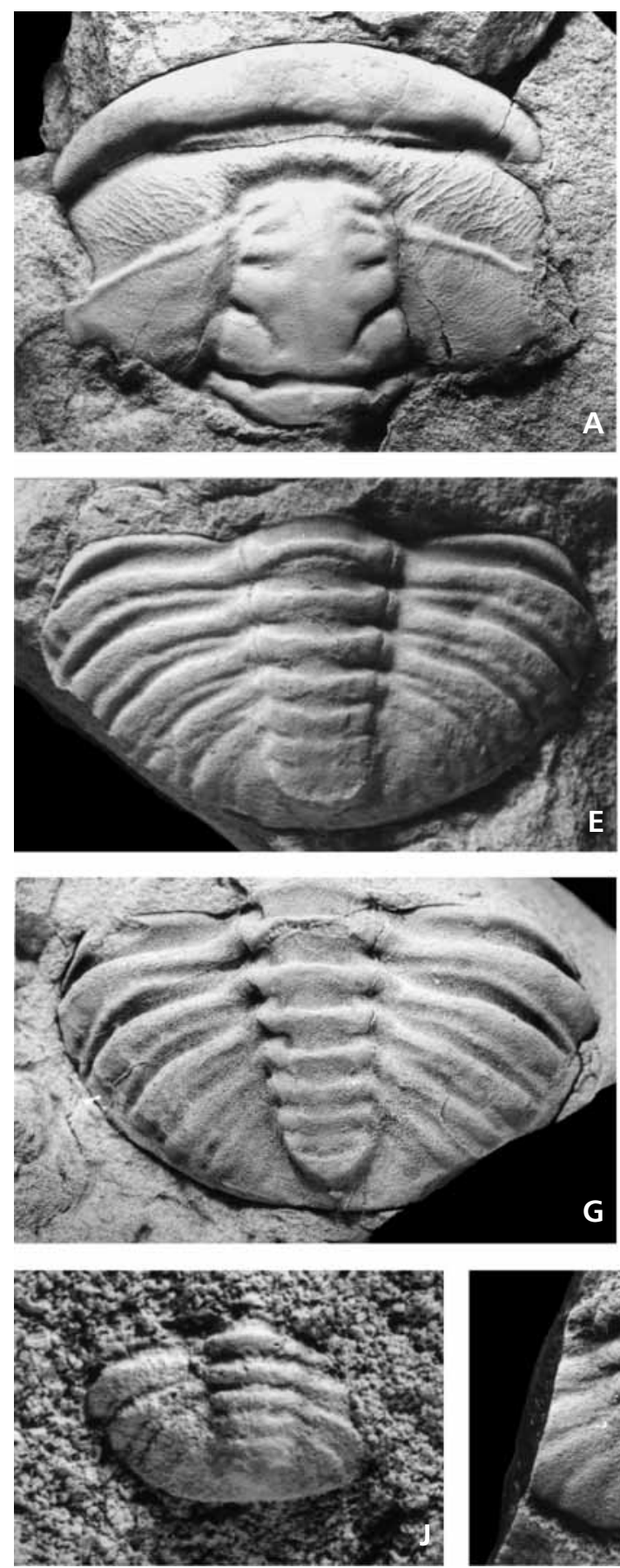
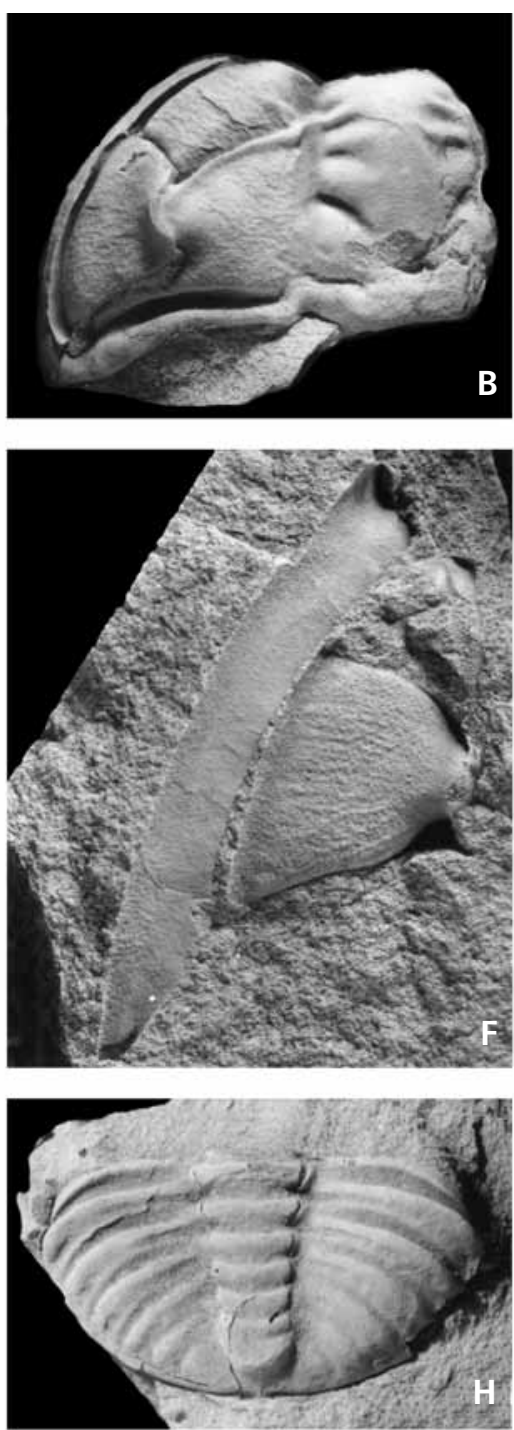
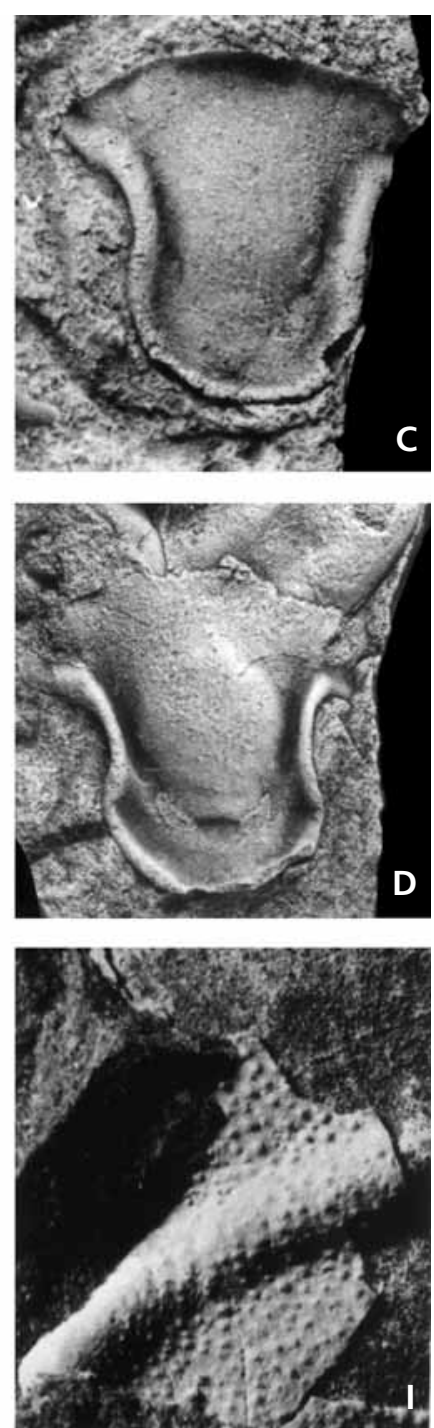

Figure 2. Ptychoparia dubinka sp. nov. Jince Formation, Skryje Shale, lower part of Eccaparadoxides pusillus Zone. Localities: Skryje, Dubinky Hill (A, B, D-I), Týřovice, Studená hora Hill (C). • A - incomplete cranidium, internal mould, ČGÚ VK $222, \times 1.8$ • B - incomplete cranidium with left free cheek, internal mould, ČGÚ VK 223, × 1.5. • C - hypostome, internal mould, ČGÚ VK 224, × 4.3. • D - hypostome, internal mould, ČGÚ VK $227, \times 4.2$. •E - holotype, pygidium, internal mould, ČGÚ VK 225, × 2.2. • F - librigena, internal mould, ČGÚ VK 226, × 2.0. • G - pygidium, internal mould, ČGÚ VK 228, $\times 2.9 \cdot \bullet \mathrm{H}$ - pygidium, internal mould, ČGÚ VK 229, × 1.8. $\bullet$ I - detail of microornament in fixigena, ČGÚ VK 230, ×6.5. Ptychoparia striata (Emmrich, 1839). Mileč Formation, Mileč Sandstone (J, K). Locality: Malá Pleš near Kouřimecká myslivna (J, K). J - pygidium, internal mould, ČGÚ VK $231, \times 3.5$. $\mathrm{K}$ - pygidium, internal mould, ČGÚ VK 232, × 3.5. Ptychoparia sp. Jince Formation, Eccaparadoxides pusillus Zone, Acadolenus snajdri subzone. Locality: Jince, temporary excavation $=$ locality No. 2 of Fatka \& Kordule (1992). $\bullet$ L - incomplete cranidium, internal mould, ČGÚ VK $233, \times 2.5$. 
Ptychoparia dubinka sp. nov. is probably a descendant of Ptychoparia striata from the basal conglomerates and sandstones of the Mileč Formation. A comparison with the specimens of $P$. striata from the Mileč Formation is difficult because of their rarity and poor preservation. New material allows confident differentiation of the species based on the higher number of axial rings in the pygidial axis of $P$. dubinka. Even complete specimens of $P$. dubinka have formerly been confused with $P$. striata, probably due to less favourable preservation in the sandstone at the Pod trním locality. The majority of well preserved specimens of $P$. dubinka have been found at Dubinky Hill (Kordule 1999).

The exoskeleton of $P$. dubinka is generally larger than that of $P$. striata. Jaekel (1901) figured the complete specimen of $P$. dubinka from the sandstone intercalation from the Pod trním locality near Týrovice. In this specimen, poorly preserved paired structures below the first to sixth axial rings of the axis are visible. He suggested that these structures are the remains of appendages of the ventral exoskeleton (coxa and endopodite). Šnajdr (1958, p. 190) did not support this opinion. However, new finds by the present author indicate that the original opinion of Jaekel (1901) was correct.

Occurrence. - Skryje-Týřovice area: Jince Formation, lower and middle part of the Skryje Shale and their stratigraphical equivalents (intercalation of the Týrovice Conglomerate in NE part of the area); localities Studená hora Hill near Týřovice, SE slope of Mileč Hill, Pod trním, slope Dlouhá hora, Dubinky Hill, Podmokelský mlýn, Lípa Hill, Mlečice, and Biskoupky.

\section{Ptychoparia cf. striata (Emmrich, 1839) Figure 6N}

Material. - One slightly deformed cranidium.

Description. - The specimen is similar to Ptychoparia striata, but differs in shortly conical glabella with preserved $\mathrm{S} 1, \mathrm{~S} 2$ and S3, by poorly defined genal caeca, and external surface of cephalon covered by coarser tubercles than in P. striata. $\mathrm{LCr} / \mathrm{LAB} 6.4$. Other parts of the exoskeleton are unknown.

Remarks. - The specimen undoubtedly belongs to Ptycho- paria, but differs from $P$. striata by its coarser ornament with larger tubercles. The number of glabellar furrows is unclear because $\mathrm{S} 4$ is not distinct; its absence may be a result of incomplete preservation.

Occurrence. - Jince area; Jince Formation, lower parts of the Eccaparadoxides pusillus Zone; Vystrkov, small hill N of the road from Jince to Velcí.

\section{Ptychoparia? sp. A}

Figure 6M

Material. - Single cranidium preserved as internal mould in fine-grained brown-purple sandstone.

Description. - The cranidium is $16 \mathrm{~mm}$ long and $24 \mathrm{~mm}$ wide, slightly deformed. It differs from Ptychoparia striata (Emmrich) by wide (tr.) and convex cephalic border of unusual length (sag.). LCr/LAB about 6. Cephalic border separated from the glabella by a narrow and deep border furrow. Glabella slightly elevated above surface of fixigenae, of bluntly conical outline and with inconspicuous S1 to S4. Preglaberal field bears narrow and weakly defined transverse ridge, which joins the fixigenae. Fixigenae vaulted with ocular ridges, anterodorsally extended and connected with palpebral lobes of moderate size. Other parts of dorsal exoskeleton are unknown.

Remarks. - The preservation obscures the presence of S4 and the convexity of preglaberal field. Despite the described differences, the possibility that the cranidium is an unusually deformed cephalon of $P$. striata cannot be entirely excluded.

Occurrence. - Jince area; Jince Formation, lower part of the Eccaparadoxides pusillus Zone (Acadolenus snajdri Subzone); locality Rejkovice - Ve žlutých.

\section{Mikaparia gen. nov.}

Type species. - Mikaparia milena gen. et sp. nov.; Middle Cambrian, Czech Republic.

Derivation of name. - After the nickname for the female name Milena.

Figure 3. Ptychoparia dubinka sp. nov. Jince Formation, Skryje Shale, lower part of Eccaparadoxides pusillus Zone (A-F). Localities: Skryje, Dubinky Hill (A-C, E, F), Skryje, Pod trním (D). • A - incomplete specimen, internal mould, ČGÚ VK 234, × 1.4. • B - cranidium, internal mould, C̆GÚ VK 235, × 1.7. $\bullet \mathrm{C}$ - cranidium, latex cast of external mould, ČGÚ VK $236, \times 2.0$. $・ \mathrm{D}$ - complete specimen, internal mould uncoated with ammonium chloride, showing spinose pleurae, C̆GÚ XB 46a, × 1.6. $\bullet$ E - incomplete cranidium, latex cast of external mould, ČGÚ VK 237, × 2.4. • F - cranidium, internal mould, ČGÚ VK 238, × 1.6 . 
Vratislav Kordule - Ptychopariid trilobites in the Middle Cambrian of Bohemia
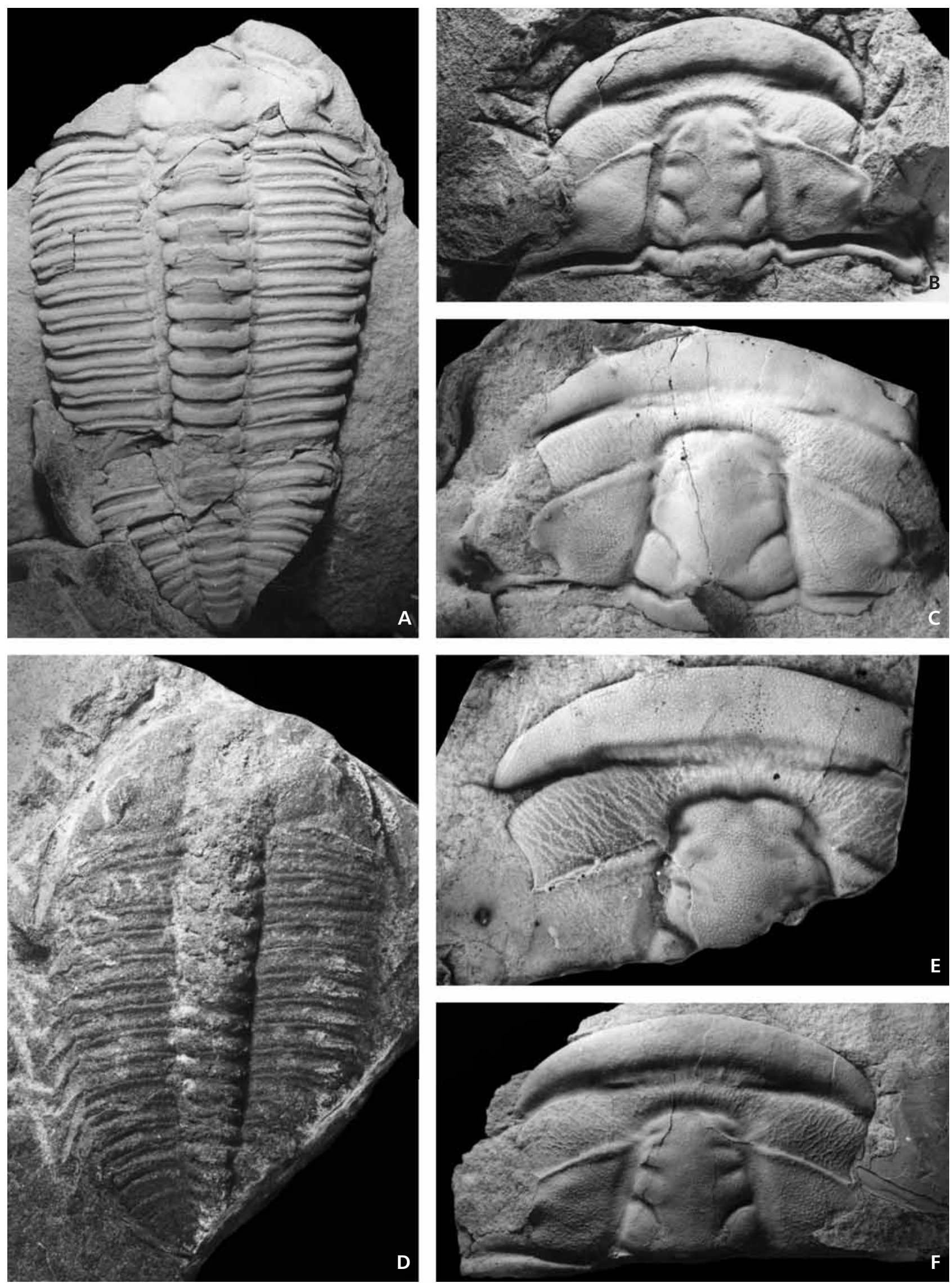
Diagnosis. - Glabella tapering forward, with weakly rounded anterior; four pairs of glabellar furrows; cephalic border short (sag.); anterior border furrow deep; genal spine conspicuous, long, weakly tapering; genal caeca weakly defined on external surface of preglabelar field, preocular field of fixigenae and librigenal field of librigenae; pygidium with six to eight rings and terminal piece, pleural field with distinct pleural furrows; interpleural furrows obscure or weakly defined; surface of cephalon with minute tubercles.

Discussion. - Mikaparia is closely related to Ptychoparia, but differs by its less prominent and shorter (sag.) cephalic border. Unlike Ptychoparia, the genal caeca of Mikaparia is less prominent on the external surface of the cranidium, and the courses of the canals are often overprinted by dominant minute tubercles. Genal spine of Mikaparia is long, almost straight and only gently tapering backward; the spine of Ptychoparia is shorter, curved and rapidly tapering. Ribs in pygidial pleural field are fused in Mikaparia, with only pleural furrows present. Unlike Ptychoparia, interpleural furrows are generally absent in Mikaparia. Pygidium of Ptychoparia is shorter, more transverse, with 5-6 rings on a gently tapering axis in contrast to the longer and narrower (tr.) axis of Mikaparia.

The new genus is present both in the Jince and Skryje-Týřovice areas, but particular species are restricted to distinct stratigraphical levels. Mikaparia mutica is restricted to the upper half of the Eccaparadoxides pusillus Zone in the Skryje-Týřovice area. Mikaparia milena sp. nov. is very rare in the lower two-thirds of the Jince Formation in the Jince area, but becomes abundant in the Paradoxides gracilis Zone. In 30 metre-thick succession of this zone, the species M. milena sp. nov. is slightly more frequent than Ptychoparia striata (Emmrich). It is noteworthy that this is also evident from the disproportion of the illustrations by Barrande (1852, pls 14, 29), and new collecting has supported this disparity. It is difficult to undertand why almost all ptychopariid trilobites have been incorporated under the name Ptychoparia striata. This confusion is probably historically based. Because $P$. striata was one of the earliest described trilobites in Bohemia, it has since been considered as the perfectly known, unproblematic taxon, and its splitting into several particular species has been difficult to accept.
Species included. - Mikaparia mutica (Hawle \& Corda, 1847); Middle Cambrian, Bohemia, Czech Republic. Mikaparia milena sp. nov.; Middle Cambrian, Bohemia, Czech Republic.

\section{Mikaparia milena sp. nov.} Figure $4 \mathrm{~A}-\mathrm{H}$

1852 Conocephalites striatus Emmrich. - Barrande (partim), pl. 14, figs 1, 6, pl. 29, fig. 39.

1944 Ptychoparia striata (Emmrich). - Růžička, p. 6, text-fig. 4 (refigured by Šnajdr, 1958, pl. 39, fig. 2).

1955 Ptychoparia striata Emmrich. - Hupé, p. 129, fig. III/1.

1958 Ptychoparia striata (Emmrich, 1839). - S̆najdr (partim), p. 185 , text-fig. 40 , pl. 38 , figs 17,18 , pl. 39 , figs 1,2 , pl. 40, figs 3,5 .

1959 Ptychoparia striata (Emmrich). - Moore, p. O233, fig. 170:6.

1970 Ptychoparia striata (Emmrich, 1839). - Horný \& Bastl (partim), pl. 4, fig. 1, Catalogue pp. 301, 302.

1989 Ptychoparia striata. - Prokop, fig. on p. 155.

1990 Ptychoparia striata (Emmrich, 1839). - Šnajdr, p. 94, fig. on p. 95.

1992 Ptychoparia sp. nov. - Fatka \& Kordule, pl. 2, fig. 7.

1993 Ptychoparia striata (Emmrich). - Chlupáč, p. 156, pl. 1, fig. 11.

1996 Ptychoparia sp. nov. - Kordule, pl. 2, fig. 6.

2002 ?Ptychoparioides sp. - Valíček \& Szabad, p. 80, pl. 1, fig. 5 .

Holotype. - Complete, slightly deformed specimen preserved as internal mould in silt shale, figured in Fig. 4H, housed in the palaeontological collections of the Czech Geological Survey, Prague (ČGÚ VK 243).

Derivation of name. - After a woman named Milena.

Type horizon and locality. - Jince Formation, middle part of the Eccaparadoxides pusillus Zone; Czech Republic, Rejkovice near Jince (locality No. 14 in Fatka \& Kordule 1992).

Material. - Several tens of complete specimens and nume-

Figure 4. Mikaparia milena sp. nov. Jince Formation, Acadolenus snajdri Subzone (G), middle part of Eccaparadoxides pusillus Zone (H), Interval Zone between Eccaparodoxides pusillus Zone and Paradoxides gracilis Zone (B), Paradoxides gracilis Zone (A, C-F). Localities: Jince, probably slope called Vinice Hill (A, D, F), Jince, Vystrkov Hill (B), Felbabka (C, E), Rejkovice, Ve žlutých (G) = locality No. 11 of Fatka \& Kordule (1992), Rejkovice, locality No. 14 of Fatka \& Kordule (1992) (H). • A - complete specimen, internal mould, specimen figured by Barrande (1852) on pl. 29, fig. 39, NM L 15178 (IT 537, ČC 327), × 1.3. • B - cephalon, internal mould, ČGÚ VK 239, × 3.2. • C - cephalon with part of thorax, internal mould, ČGÚ VK 240, $\times 1.5$. $\bullet$ D - complete specimen, internal mould, NM L $15176 \mathrm{a}, \times 1.2 . \bullet \mathrm{E}$ - pygidium with posterior part of thorax showing terminal parts of pleurae, internal mould, ČGÚ VK $241, \times 1.5$. • F - pygidium, internal mould, specimen figured by Barrande (1852) on pl. 14, fig. 6, NM L 12665 originally figured with 7 rings, but actually only with 6 rings and terminal piece, $\times 2.1 . \bullet \mathrm{G}-$ pygidium, internal mould, ČGÚ VK $242, \times 2.3$. $\bullet$ H - holotype, complete specimen, internal mould, ČGÚ VK 243, × 1.5 . 
Vratislav Kordule - Ptychopariid trilobites in the Middle Cambrian of Bohemia
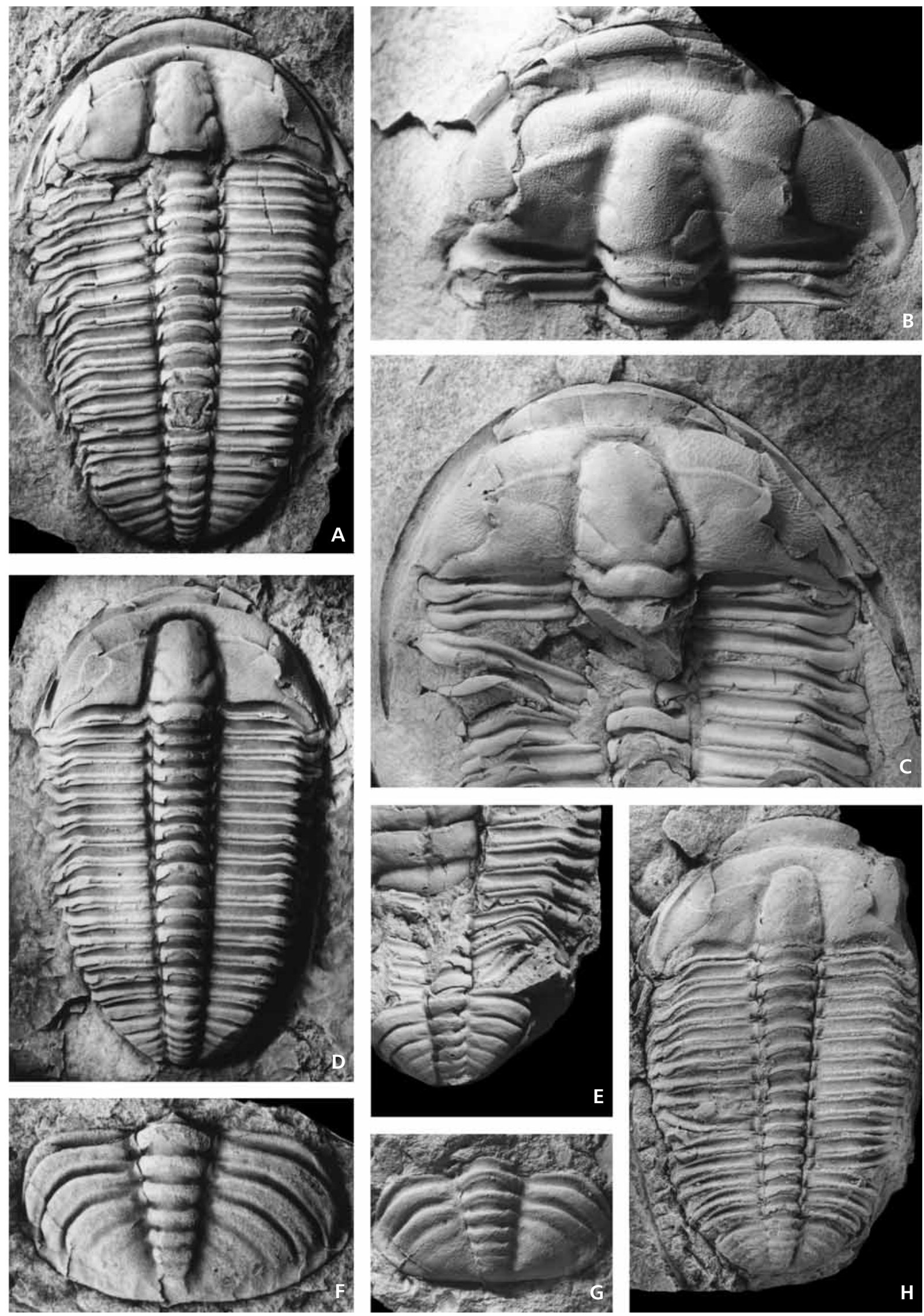
rous isolated parts of the exoskeletons mainly from the $\mathrm{Pa}$ radoxides gracilis Zone.

Diagnosis. - Mikaparia with subtrapezoidal, forward tapering and anteriorly rounded glabella; S1 long, strongly curved backward, S2, and S3 shorter and shallower, S3 almost normal to sagittal axis; S4 weekly impressed; anterior border conspicuous, short (sag.), gently convex; average $\mathrm{LCr} / \mathrm{LAB}$ cca 10.0; pygidial axis with six rings and subtriangular terminal piece; five ribs on pleural field.

Description. - Dorsal exoskeleton heteropygous, elongated oval in outline, generally $60 \mathrm{~mm}$ in length, exceptionally nearly $90 \mathrm{~mm}$ long. Cephalon semicircular with long genal spines that extend backward to fifth thoracic segment. Glabella subtrapezoidal, tapering forward, rounded anteriorly, defined by deep and wide axial and preglabellar furrows. Glabella bears four pairs of glabellar furrows, S1 longest, oblique, strongly curved backward; S2, S3 are shorter and shallower; S3 runs almost normal to sagittal axis; S4 weekly impressed. Occipital ring highly vaulted with small median node. Occipital furrow deep abaxially, with shallow axial portion curved forward. Preglabelar field vaulted, low. Anterior border strongly convex, short, with LCr/LAB near 10.0. Anterior border furrow deep and wide (sag.). Paradoublure furrow is not present. Fixigena as wide (tr.) as glabella, gently convex (exsag.). Palpebral lobe of moderate size, opposite to L2 and L3, slightly raised above surface of fixigena. Ocular ridge prominent, slightly inclined backward, uniting palpebral lobe with axial furrow opposite to S4. Librigena subtriangular in general outline, gently vaulted (exsag.), with evenly wide (tr.) border and narrow and shallow border furrow. Facial sutures differentiated; $\alpha-\beta$ convex adaxially, $\beta-\gamma$ convergent, and $\varepsilon-\omega$ divergent to the genal angle. The rostral plate is transversally elongated, convex in ventral view. Hypostome with robust median body anterolaterally extended into short rounded extensions. Preocular area of fixigena and librigena, and the preglabellar area, covered by weakly defined genal caeca composed of radially arranged anastomosing fine ridges.

Long thorax of fourteen segments gently tapering backward. Axis strongly vaulted (tr.), almost evenly broad (tr.) along whole length, well defined by deep axial furrows. Pleurae fulcrate, with horizontal proximal and steeply sloping distal parts. Pleural furrow broad, concave (exsag.) tapering and deepening toward pleural tip. Anterior pleural band narrower than posterior band, which gently expands abaxially. Pleural extremities shortly pointed.

Pygidium subpentagonal. Pygidial axis convex, with six rings and terminal subtriangular piece. Lateral lobes with five ribs on each pleural field. Ribs separated by deep pleural furrows distinct toward narrow (exsag.) border. The first and second ribs bear shallow interpleural furrow, but repining ribs are without furrows. The pygidial doublure is narrow, gently extending anterolaterally.

External surface of exoskeleton densely covered by minute, uniformly sized tubercles.

Remarks. - Valíček \& Szabad (2002, pl. 1, fig. 5) figured a cranidium from the basal beds of the Jince Formation. These authors referred this specimen to Ptychoparioides sp., but it probably belongs to Mikaparia milena sp. nov. However, the specimen is kept in a private collection that was not available to the present author.

The earliest occurrence of the new species is in the middle of the Eccaparadoxides pusillus Zone of the lower Jince Formation. The specimens are rare there and in the following sequence cca $230 \mathrm{~m}$ thick of siltstone and mudstone. The species becomes abundant in the Paradoxides gracilis Zone, in association with Ptychoparia striata. This explains why all specimens as yet figured come from this upper level (Barrande 1852, Šnajdr 1958).

Mikaparia milena sp. nov. is probably an ancestor of Mikaparia mutica (Hawle \& Corda, 1847), which is known from the Skryje-Týřovice area. The latter has seven to eight rings on the pygidial axis and terminal piece. Barrande (1852, pl. 14, fig. 6) figured a pygidium that belongs to M. milena from the Jince area. This specimen has seven rings on its pygidial axis, but this feature is the combination of a damaged axis and schematic drawing. A similar situation concerns another pygidium (Barrande 1852; pl. 29, fig. 39). All studied specimens have only six rings and a terminal piece.

Occurrence. - Jince area, Jince Formation, in all trilobitebearing localities from the Acadolenus snajdri Subzone (rare) to Paradoxides gracilis Zone (frequent).

\section{Mikaparia mutica (Hawle \& Corda, 1847)}

Figures 5, 6, 7

1847 Conocoryphe mutica Hawle \& Corda, 1847; pp. 24, 167.

1852 Conocephalites striatus Emmrich. - Barrande (partim), pl. 14, fig. 7.

1896 Ptychoparia striata tenuis Pompeckj. - Pompeckj, p. 542 , pl. 17, fig. 9 .

1958 Conocoryphe Hawle \& Corda, 1847. - Šnajdr (partim), p. 156.

1958 Ptychoparia striata (Emmrich, 1839). - Šnajdr (partim), p. 185, pl. 39, fig. 5, pl. 40, figs 2, 4, 6, 17.

1970 Ptychoparia striata (Emmrich, 1839). - Horný \& Bastl (partim), p. 301.

1982 Conocoryphe mutica Hawle \& Corda. - Šnajdr, p. 67, pl. 3 , fig. 4 . 

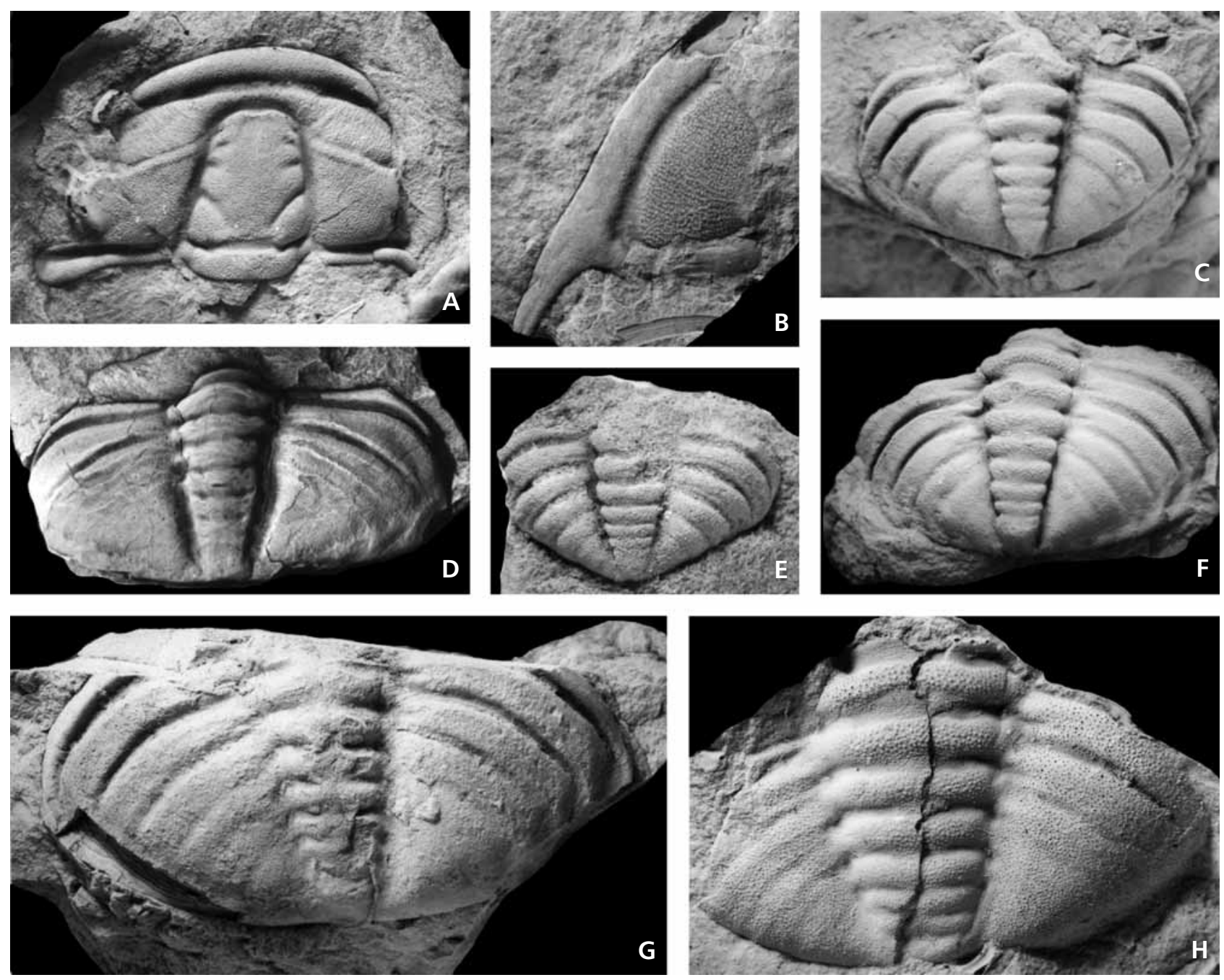

Figure 5. Mikaparia mutica (Hawle \& Corda, 1847). Jince Formation, Skryje Shale, middle and upper part of Eccaparadoxides pusillus Zone. Localities: Skryje, Buchava (B, C, F), Skryje, slope Dlouhá hora (A, G), Dubinky Hill (H), Týřovice, Pod hruškou (D), Skryje, Plazy (E). • A - cranidium, latex cast of external mould, ČGÚ VK 248, × 2.8. • B - librigena, internal mould, ČGÚ VK 249, × 1.4. •C - pygidium, internal mould, C̆GÚ VK 250, × 2.8. • D - pygidium, internal mould, NM L 17851, × 1.7, figured as lectotype by Šnajdr (1982) on pl. 3, fig. 4. E - pygidium, of small specimen, internal mould, ČGÚ VK 251, ×6.5. • F - pygidium, internal mould, ČGÚ VK 252, × 2.3. $\bullet \mathrm{G}-$ pygidium, internal mould, ČGÚ VK 253, × 1.7. $\bullet \mathrm{H}-$ pygidium, latex cast of external mould showing spinose ornament, ČGÚ VK $247, \times 2.4$.

1983 mutica, Conocoryphe Hawle \& Corda. - Šnajdr, p. 174 [as Ptychoparia mutica (H. \& C. 1847)].

1989 Ptychoparia mutica (Hawle \& Corda). - Pek \& Vaněk, pp. 28, 51 (for striata tenuis, Ptychoparia Pompeckj, 1895).

1997 Ptychoparia tenuis Pompeckj, 1895. - Vokáč, p. 16, pl. 1, fig. 5.

2001 Ptychoparia tenuis Pompeckj, 1895. - Vaněk \& Valíček, p. 6.

Lectotype.-(SD Šnajdr 1958, p. 185). Deformed pygidium preserved as internal mould in siltstone, from the Hawle collection, with original label attached, figured here in Fig. 5D), housed in the palaeontological collection of the National Museum, Prague (L 17851).
Type horizon and locality. - Jince Formation, upper part of the Eccaparadoxides pusillus Zone; Czech Republic, Týřvice, Pod hruškou locality.

Material. - Two damaged complete specimens, about twenty cranidia, twenty pygidia.

Diagnosis. - Mikaparia with subtrapezoidal, forward tapering and anteriorly rounded glabella; S1 long, strongly curved backward, S2 and S3 shorter and shallower, S3 almost normal to sagittal axis; S4 weekly impressed; anterior border narrow (sag.), gently convex; average LCr/LAB cca 9.0; pygidial axis with seven to eight rings and subtriangular terminal piece; six ribs on pleural field; interpleural furrows absent; genal caeca obscure on external surface of cephalon. 

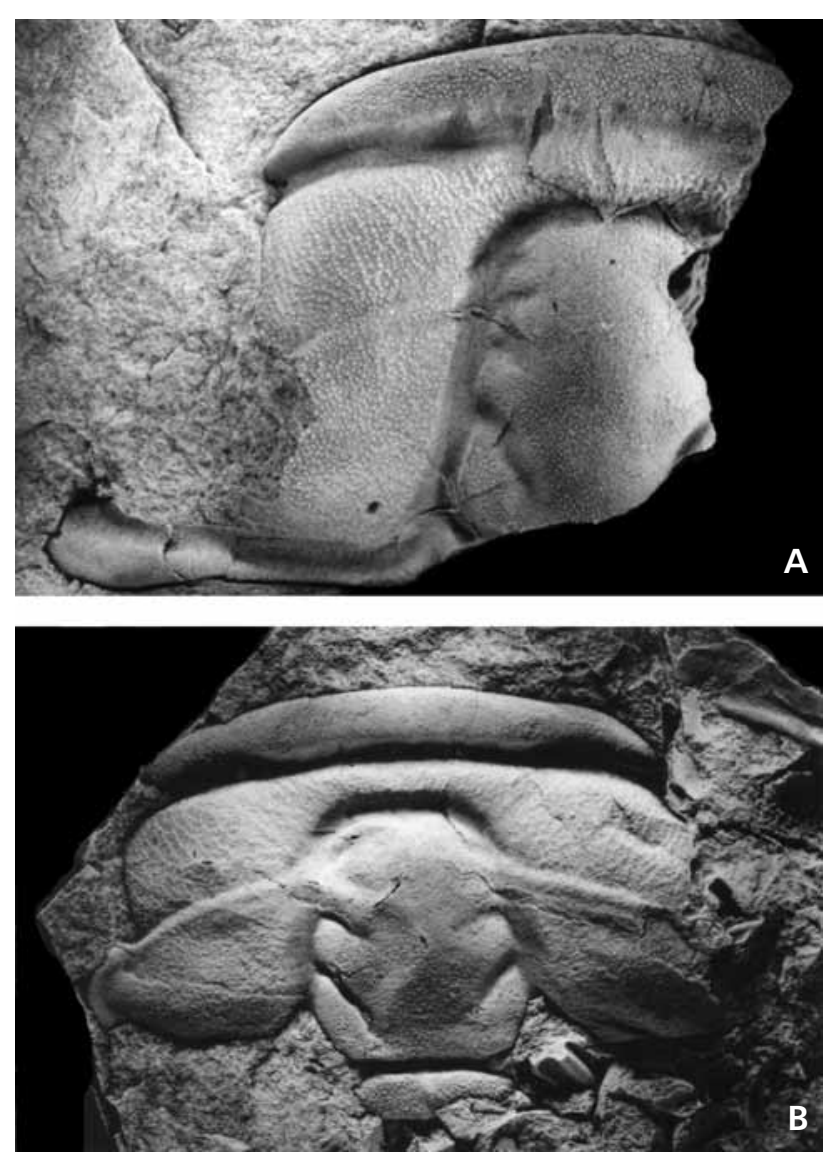

Figure 6. Mikaparia mutica (Hawle \& Corda, 1847). Jince Formation, Skryje Shale, middle part of Eccaparadoxides pusillus Zone. Locality: Skryje, Buchava. • A - incomplete cranidium, internal mould, C̆GÚ VK $244, \times 1.5$. • B - cranidium, internal mould, ČGÚ VK $245, \times 1.8$

Remarks. - The exoskeleton is generally similar to that of M. milena sp. nov. Major differences are as follows: (1) LCr/LAB about 9, depending on tectonic deformation and the age of specimen, range between 8 and 10; (2) internal surface of the cephalic shield has the same radial canals of genal caeca and very small tubercles, but the external surface of cephalon shows only tubercles; (3) pygidial axis of seven rings and terminal piece, occasionally with eight rings and terminal piece; (4) deep pleural furrows define six ribs in the pleural field of the pygidium. Interpleural furrows are absent (rarely their traces may be seen only on first three ribs, but this may be due to deformation).

It has been suggested that the name Conocoryphe mutica (Hawle \& Corda, 1847) is invalid (Barrande 1852, Šnajdr 1958). It seems likely that the main reason for this lies in the incorporation of Hawle's specimens into Barrande's collections, in which the type specimen of Conocoryphe mutica was not stored separately. Revising Barrande's collection, Šnajdr (1982, pl. 3, fig. 4) found and figured one of the original syntypes of Hawle \& Corda (1847). This specimen (an internal mould of a pygidium) is labeled in original ink, and was selected by Šnajdr (1958) as the lectotype of Conocoryphe mutica Hawle \& Corda, 1847 , but the same author synonymised $C$. mutica with Ptychoparia striata.

The common length of holaspid specimens is 60 to $70 \mathrm{~mm}$, but some specimens seem to have reached $100 \mathrm{~mm}$ as might be inferred from exoskeletal fragments. Pygidia of $M$. mutica generally have seven axial rings and a terminal piece. However, the large pygidia rarely show eight axial rings and the terminal piece. This variation in the number of axial rings is unknown in any other ptychopariid taxon. This might be explained by phenotypic variability, because it seems unlikely that these pygidia belong to another ptychopariid species. Śnajdr (1982) noted that the lectotype (pygidium) of $P$. mutica bears weakly preserved interpleural furrows, but that the pygidial shield is deformed along the sagittal axis. Weak furrows reminiscent of interpleural furrows in several available pygidia are likely to have originated by compression along the sagittal axis.

The lower half of the sequence referred to the Eccaparadoxides pusillus Zone in the Skryje-Týřovice area yielded only Ptychoparia dubinka sp. nov. In the higher part of the zone, $P$. dubinka is gradually substituted by Mikaparia mutica (Hawle \& Corda, 1847). Within approximate beginning of the upper third of the Eccaparadoxides pusillus Zone, there is an overlap of the older faunal assemblage characterised by $P$. dubinka, Ptychoparioides henkli sp. nov., and Germaropyge germari with a younger assemblage. A sequence about ten metres thick, known from all accessible sites with this stratigraphical interval in the Skryje-Týřovice area, yielded both $P$. dubinka and M. mutica.

Mikaparia mutica is an important index species of the youngest faunal assemblage in the Skryje-Týřovice area, associated with Sao hirsuta, Eccaparadoxides rohanovicus, Solenopleurina tyrovicensis, Agraulos ceticephalus, Jincella prantli, Peronopsis umbonata, Condylopyge rex, Diplorrhina cuneifera and other agnostids.

Occurrence. - Skryje-Týřovice area: Jince Formation, upper part of the Skryje Shale; localities Studená hora Hill near Týřovice, Pod hruškou near Týřovice, Luh and Plazy near Skryje, slope Dlouhá hora, Dubinky Hill, and Buchava.

\section{Genus Ptychoparioides Růžička, 1940}

1940 Ptychopairoides Růžička; Růžička, p. 5.

1953 Ptychoparioides Růžička, 1939. - Přibyl, p. 63.

1958 Ptychoparioides Růžička. - Šnajdr, pp. 184, 186, 190.

1959 Ptychoparoides Růžička. - Moore (partim), p. O233, pl. 170/8a, non 8b (= Ptychoparia striata). 
1989 Ptychoparioides Růžička 1940. - Pek \& Vaněk, p. 57 (by the authors considered as Ptychoparia mutica Hawle \& Corda, 1847).

2001 Ptychoparioides Růžička, 1940. - Vaněk \& Valíček, p. 7.

Type species. - Solenopleura torifrons Pompeckj, 1896; Middle Cambrian, Czech Republic.

Remarks. - According to chapter 70.3 of the Zoological Code (fourth edition), the type species of the genus Ptychoparioides Růžička, 1940 is defined as Solenopleura torifrons Pompeckj, 1896. The selection of Ptychoparioides nobilis Rủžička, 1940 as the type species is invalid because it is based on an incorrectly identified specimen, which actually belongs to Solenopleura torifrons Pompeckj, 1896. In addition, the type specimen selected by Růžička (1940) did not originate from the original collection of Pompeckj (1896).

Emended diagnosis (Růžička 1940). - Glabella highly convex, bluntly conical, anteriorly rounded, extending nearly toward border furrow; axial furrows deep; occipital ring vaulted, with small median node; S1, S2 and S3 shallow; preglabellar field flat; anterior border short (sag.), high, convex, separated from glabella by deeply concave border furrow; ocular ridges prominent; palpebral lobes small; genal caeca obscure; genal spine short; thorax of 14 segments; pygidium transverse, with axis with three to five rings and large terminal piece; pleural furrows present, interpleural furrows absent; surface of exoskeleton finely tuberculate.

Discussion. - Ptychoparioides differs from Ptychoparia and Mikaparia by having a conical instead of a trapezoidal or subtrapezoidal glabella. The preglabellar field of Ptychoparioides is low and depressed, and the anterior border is shorter (sag.) and raised and shelf-like, unlike the convex and broad preglabellar field of Ptychoparia. Librigena of Ptychoparioides extend into short spines not extending beyond the second segmnet of the thorax. Pygidium of Ptychopariodes is shorter, less arched and more transverse than in Ptychoparia and Mikaparia, with weakly defined pleural and interpleural furrows. It is worth noting that the general morphology of Ptychopariodes is similar to that of Conocoryphe, but there are striking differences in the facial suture courses between these genera. The genal caeca of Ptychoparioides is obscure compared to Ptychoparia.

The diagnosis of the genus given by Růžička (1940) is inaccurate because it is based on poorly preserved specimens from sandstone. The genus was therefore considered invalid by Richter (1940) and Šnajdr (1958). It was synonymised with Ptychoparia Hawle \& Corda, 1847 and its type species put into synonymy with Ptychoparia striata

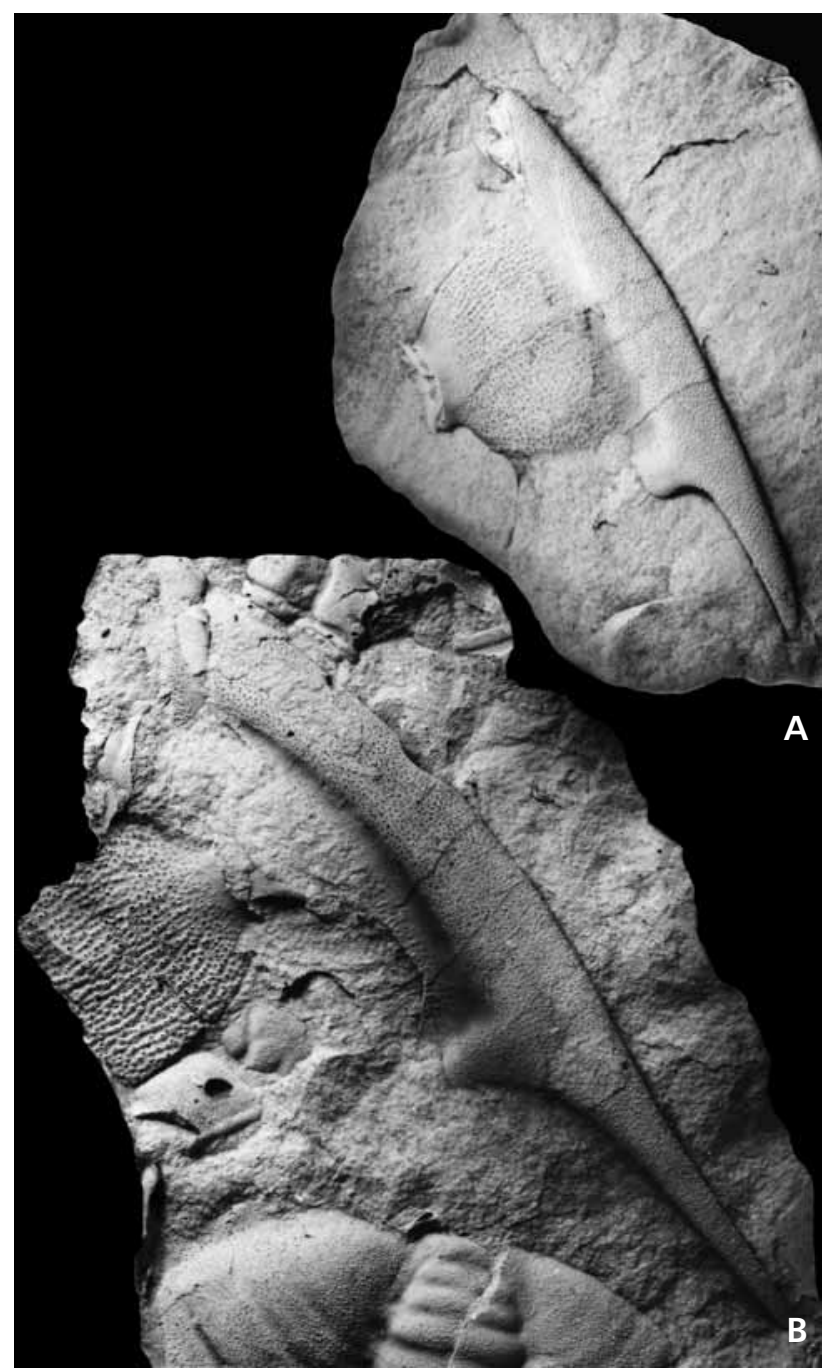

Figure 7. Mikaparia mutica (Hawle \& Corda, 1847). Jince Formation, Skryje Shale, upper part of Eccaparadoxides pusillus Zone. Locality: Skryje, slope Dlouhá hora (A), Dubinky Hill (B). • A - librigena, latex cast of external mould, ČGÚ VK 246, × 2.0. • B - librigena showing long spine, latex cast of external mould, ČGÚ VK 247, × 1.6.

(Emmrich, 1839). However, the well preserved specimens from fine-grained sediments of the Skryje-Týrovice and Jince areas (Kordule 1996) indicate the validity of the genus and allow further refinement of the generic diagnosis.

\section{Ptychoparioides torifrons (Pompeckj, 1896)}

Figure $8 \mathrm{~A}-\mathrm{G}$

1896 Solenopleura torifrons Pompeckj; Pompeckj, p. 546, pl. 15, fig. 22.

1907 Solenopleura torifrons Pompeckj. - Kafka \& Perner, fig. 243/7.

1940 Ptychoparioides nobilis Růžička; Růžička, p. 5, pl. 2, figs $1-4$, pl. 3 , figs 4,5 . 
1940 Ptychoparioides torifrons Růžička; Růžička, p. 6, pl. 2, figs 6-9, pl. 3, figs 6-8.

1944 Ptychoparioides nobilis Růžička; Růžička, p. 5, text-fig. 5.

1953 Ptychoparioides nobilis Růžička. - Přibyl, p. 63.

1955 Ptychoparoides nobilis Růžička. - Hupé, p. 129, fig. 11/4.

1958 Ptychoparia striata (Emmrich, 1839). - Šnajdr, p. 184 (partim), pp. 186, 190, pl. 38, fig. 20.

1959 Ptychoparoides nobilis. - Moore, p. O233, fig. 170: 8a, non 8b (= Ptychoparia striata).

1970 Ptychoparioides nobilis Růžička, 1940. - Horný \& Bastl, p. 217, as Ptychoparia striata.

1989 nobilis, Ptychoparioides. - Pek \& Vaněk, p. 45, as Ptychoparia mutica.

2001 Ptychoparioides torifrons Růžička, 1940. - Valíček, p. 7.

Lectotype. - Cranidium preserved as internal mould in sandstone, figured by Pompeckj (1896, pl. 15, fig. 22a), housed in the Geologische Bundesanstalt, Wien, Austria, coll. No. 1896/04/0047. The original selection of Růžička (1940) is invalid because the lectotype was not selected from the type specimens of Pompeckj (1896).

Type horizon and locality. - Middle Cambrian, Mileč Formation, upper part of the formation; Czech Republic, Týřovice, Na Kamenných hůrkách locality.

Material. - Eight cranidia and five pygidia.

Diagnosis. - Ptychoparioides with highly convex, anteriorly subtruncate glabella; S1 and S2 are shallow, inclined backward, S3 and S4 are short, shallow, transverse; preglabelar field flat; cephalic border conspicuously convex anteriorly; anterior border short, evenly broad (sag.), convex; separated from preglabelar field by broadly concave border furrow; ocular ridges strongly inclined backward; pygidium transverse, with axis cca $25 \%$ of pygidial width; five axial rings and terminal piece; two flat, weakly defined ribs on pleural lobes.
Remarks. - Fine details of the morphology such as genal caeca and tubercles are not preserved by the coarse sandstone of the original locality. New data about the morphology of the pygidia are based on new material from Malá Pleš Hill near Týřovice. Růžička (1940) distinguished two species, Ptychoparioides nobilis Růžička, 1940 and $P$. torifrons (Pompeckj, 1896). Revision of the specimens figured by Růžička (1940) and newly collected specimens indicate that both species are variably deformed specimens of the same species. This opinion is supported also by the drawings of Růžička (1940, pl. 3, figs 4-8), which, apart the deformation, do not show any other differences. The name $P$. nobilis is considered a subjective synonym of $P$. torifrons.

Occurrence. - Skryje-Týřovice area: basal conglomerates and sandstones of the Mileč Formation; localities Malá Pleš near Kouřimecká hájovna, Na Kamenných hůrkách near Týřovice, Mileč Hill, Slapnický mlýn. Jince Formation, Týřovice Greywackes, lower part; locality Hlohovice.

\section{Ptychoparioides henkli sp. nov.}

Figure 9A-J

1997 Ptychoparioides cf. torifrons (Pompeckj, 1895). Vokáč, p. 17, pl. 1, fig. 6.

1999 Ptychoparioides henkli sp. nov. - Kordule, p. 18 (nomen nudum).

Holotype. - Complete, slightly damaged specimen, preserved as internal mould in shale, figured in Fig. 9E. Housed in the collection of the Czech Geological Survey, Prague (ČGÚ VK 265).

Derivation of name. - After Luboš Henkl, a private fossil collector.

Type horizon and locality: Jince Formation, lower part of the Eccaparadoxides pusillus Zone; Czech Republic, Skryje, Dlouhá hora locality.

Figure 8. Ptychoparioides torifrons (Pompeckj, 1896). Mileč Formation, Mileš Sandstone (A-G). Localities: Týřovice, Na Kamenných hůrkách (A-C), Skryje, Slapnický mlýn (D, E), Malá Pleš near Kouřimecká myslivna (F, G). • A - cranidium, internal mould, NM L 28206, ×2.0. • B - cranidium, internal mould, NM L 28200, × 2.0. • C - cranidium, internal mould, NM L 19652, × 2.3. • D, E - cranidium, internal mould and its oblique view, ČGÚ MŠ $9770, \times 3.9 . \bullet F-$ pygidium, internal mould, ČGÚ VK $254, \times 3.2 \cdot \bullet \mathrm{G}$ - pygidium, internal mould, ČGÚ VK $255, \times 3.8$. $\bullet$ Ptychoparioides chlupaci sp. nov. Jince Formation, Acadolenus snajdri Subzone (H, P), Litavkaspis rejkovicensis Subzone (I-K). Localities: Rejkovice, Ve žlutých $(\mathrm{H}, \mathrm{P})=$ locality No. 11 of Fatka \& Kordule (1992); Rejkovice, Potůček (I-K). $\bullet H$ - cranidium, internal mould, ČGÚ VK 256, × 3.5. •I - cranidium, external mould showing spinose surface, ČGÚ VK 257, × 4.0. • J - cranidium, internal mould, ČGÚ VK 257, × 2.1. $・$ K - holotype, damaged complete specimen, internal mould, ČGÚ VK 258, × 2.7.•O - cranidium, internal mould, ČGÚ VK 263, × 2.4. Mikaparia mutica (Hawle \& Corda, 1847). Jince Formation, Skryje Shale (L, M). Locality: Skryje, slope Dlouhá hora. $\bullet \mathrm{L}-$ nearly undeformed cranidium preserved in siltstone with longer preglaberal field, internal mould, ČGÚ VK 260, × 1.2. $•$ M - cranidium, internal mould, C̆GÚ VK 261, × 4.5. • Ptychoparia cf. striata (Emmrich, 1839). Jince Formation, lower part of Eccaparadoxides pusillus Zone. Locality: Velcí. • N - cranidium, internal mould, ČGÚ VK 262, × 2.5. • ?Ptychoparia sp. A. Jince Formation, Acadolenus snajdri Subzone. Locality: Rejkovice, Ve žlutých = locality No. 11 of Fatka \& Kordule (1992). P - cephalon with part of thorax, internal mould, ČGÚ VK 259, × 1.8 . 
Vratislav Kordule - Ptychopariid trilobites in the Middle Cambrian of Bohemia
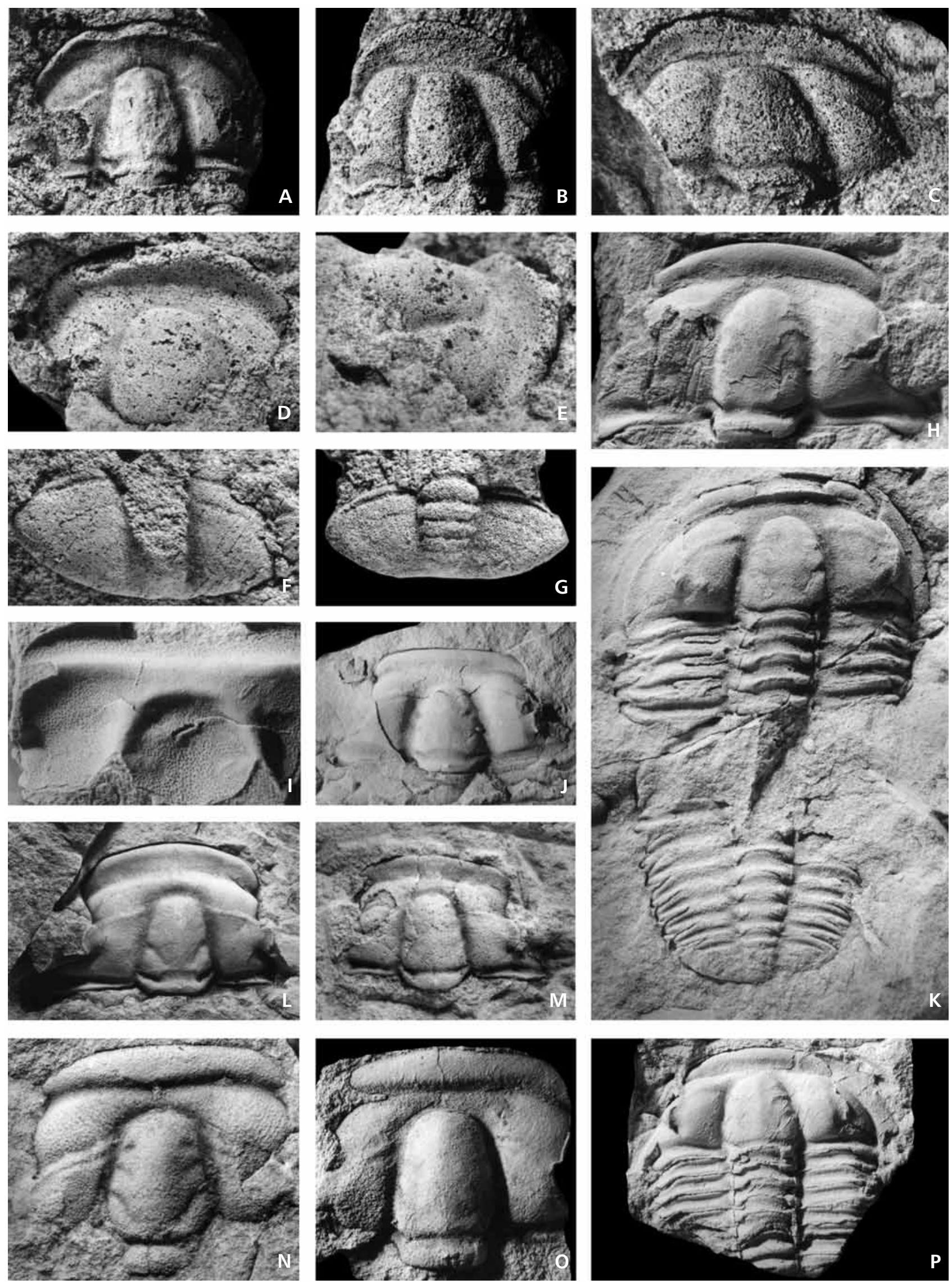
Material. - Five complete specimens, several cranidia and pygidia.

Diagnosis. - Ptychoparioides with highly convex, forward rapidly tapering glabella, which is distinctly higher than fixigenae; S1 and S2 are moderately deep and inclined backward, S3 and S4 are short, shallow, transverse; preglabelar field flat, very short; anterior border short, evenly broad (sag.), weakly convex, with edge directed anterodorsally, separated from preglabelar field by broadly concave border furrow; ocular ridges conspicuous, almost straight, strongly inclined backward towards small palpebral lobes; pygidium transverse, with axis $30-35 \%$ of pygidial width; five axial rings and terminal piece; two distinct and third weakly defined pleural furrows in lateral pygidial lobe; interpleural furrow weakly defined between the first and second pleura; third and fourth ribs poorly defined.

Differential description. - The species resembles Ptychoparioides torifrons but differs by the following features: (1) lower cephalic border less convex anteriorly and dorsally; (2) pygidium broadly rounded posteriorly, with distinctly vaulted pygidial axis having five rings and the terminal piece; (3) lateral lobes with four weakly marked ribs; three anterior pairs with distinct pleural and interpleural furrows, furrow in the fourth pair obscure.

Remarks. - This rare species is known only from the Skryje-Týřovice area. It is a probable descendent of $P$. torifrons (Pompeckj, 1896), which stratigraphically preceded it. Ptychoparioides henkli sp. nov. is similar to P. chlupaci sp. nov. but differs from the latter in having deeper S1-S4, less vaulted fixigenae, and a glabella highly raised above the fixigenae. The pygidium of $P$. henkli is larger and longer (sag.), with five rings in the axis. The length of adult specimens is larger than $P$. chlupaci.

General shape, outline of the glabella and especially the shape of the pygidium of $P$. henkli are very similar to Conocoryphe, particularly to Conocoryphe sulzeri cirina Šnajdr, 1982.

Ptychoparioides henkli, Ptychoparia dubinka and Germaropyge germari are the index taxa of the association of the lower and middle part of the Eccarapadoxides pusillus Zone in the Skryje-Týřovice area.

Occurrence. - Skryje-Týřovice area: Jince Formation,
Skryje Shale; localities slope Dlouhá hora, Dubinky Hill, Podmokelský mlýn, and Mlečice.

\section{Ptychoparioides chlupaci sp. nov.} Figure $8 \mathrm{H}-\mathrm{K}$

1996 Ptychoparioides sp. nov.; Kordule, pl. 2, fig. 4.

Holotype. - Almost complete, slightly damaged specimen, preserved as internal mould in sandstone, figured in Fig. 8. K. Housed in the collection of the Czech Geological Survey, Prague (ČGÚ VK 258) (from Knížek coll.).

Derivation of name. - In honour of the late Professor Ivo Chlupáč (1931-2002), a famous Czech palaeontologist.

Type horizon and locality. - Jince Formation, Eccaparadoxides pusillus Zone, Litavkaspis rejkovicensis Subzone; Czech Republic, Rejkovice, Potůček locality.

Material. - The holotype, a cephalon with four attached thoracic segments and four cranidia.

Diagnosis. - Ptychoparioides with slightly convex glabella, weakly tapering forward as high as fixigena, with evenly rounded anterior lobe; $\mathrm{S} 1$ and $\mathrm{S} 2$ are shallow, inclined backward, S3 and S4 are short, shallow, transverse; preglabelar field flat, very short; anterior border short, evenly broad (sag.), weakly convex anteriorly and dorsally, with edge directed dorsally, separated from preglabelar field by broadly concave border furrow; ocular ridges conspicuous, weakly curved and inclined backward towards small palpebral lobes; pygidium short (sag.) transverse, with axis cca $25 \%$ of pygidial width; three axial rings and terminal piece; two distinct and third weakly defined pleural furrows in lateral pygidial lobe; interpleural furrow weakly defined between the first and second pleura; third and fourth ribs poorly defined.

Differential description. - The species resembles Ptychoparioides torifrons, but differs by the following features: (1) cephalic border less vaulted anteriorly and dorsally; (2) fixigenae more convex, raised to almost the same level as the glabella; glabella is slightly convex; (3) librigenae extended into very short spines; (4) external surface of cepha-

Figure 9. Ptychoparioides henkli sp. nov. Jince Formation, Skryje Shales, lower part of Eccaparadoxides pusillus Zone (A-J). Localities: Skryje, Buchava (A), Skryje, slope Dlouhá hora (C-E), Skryje, locality Jahn (B, F-J). • A - cranidium, internal mould, C̆GÚ VK 264, × 2.2. • B - cranidium, internal mould, C̆GÚ VK 266, × 2.5. • C, D - cephalon with thorax, internal mould and its oblique view; note hypostome in situ, C̆GÚ P 2713, × 1.8. • E - holotype, complete specimen, internal mould with hypostome in situ, ČGÚ VK $265, \times 1.3$. • F - pygidium, internal mould, C̆GÚ VK 267, × 2.1. • G - pygidium, internal mould, ČGÚ VK $268, \times 2.0$. $・ H$ - pygidium of small specimen, internal mould, ČGÚ VK $269, \times 5.5$. $・$ I - pygidium, internal mould, ČGÚ VK 270, × 4.6. • J - pygidium, latex cast of external mould showing fine granulation, ČGÚ VK $267, \times 2.3$. 
Vratislav Kordule • Ptychopariid trilobites in the Middle Cambrian of Bohemia
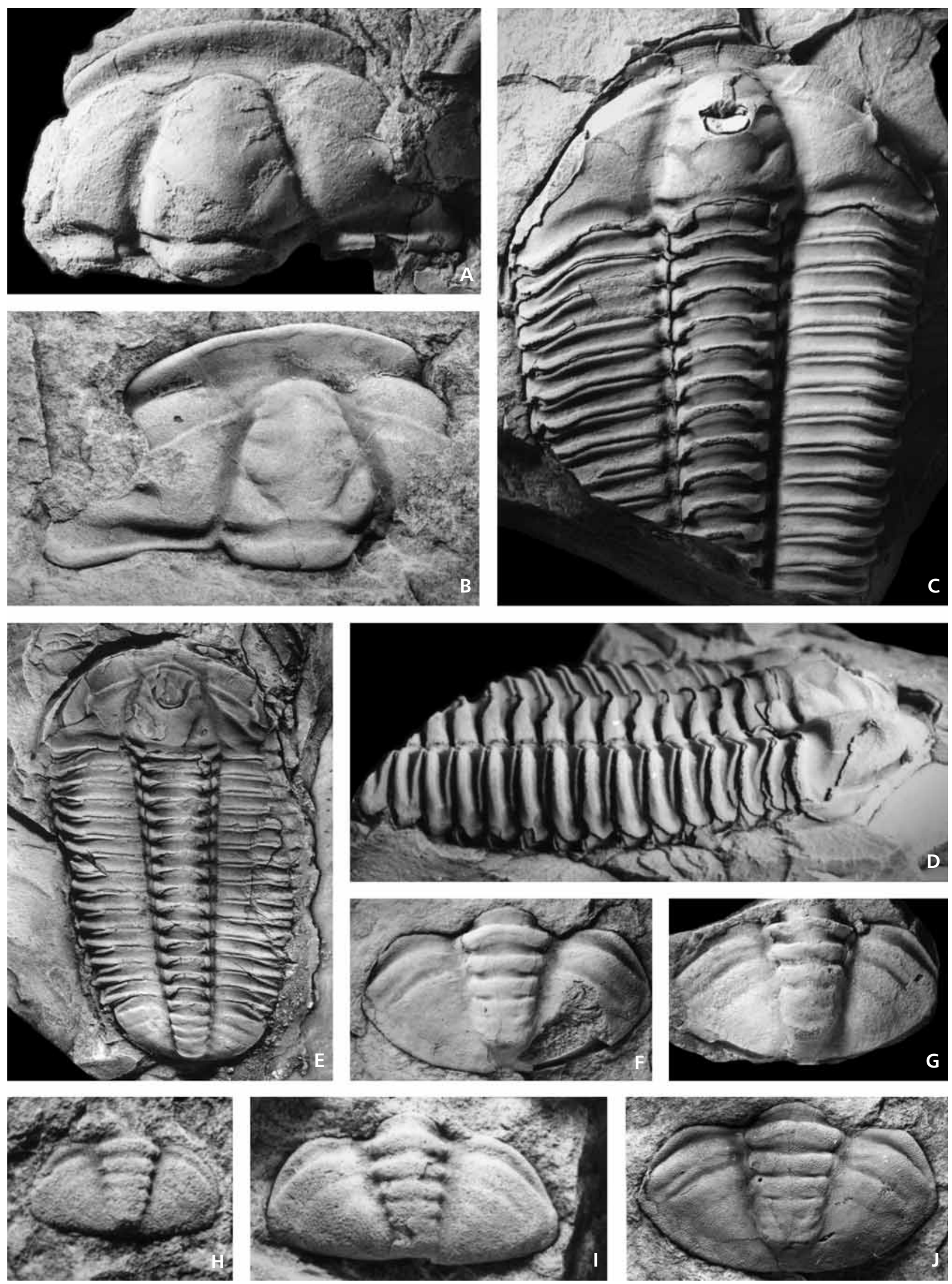
lon densely covered by very fine spines; (5) pleurae with deep pleural furrow, the terminal points of pleurae rounded; (6) Pygidium short (sag.), extended laterally; the axis has three rings and a terminal piece.

Remarks. - The new species resembles Ptychoparioides torifrons (Pompeckj, 1896), but differs by its less vaulted cephalic border and conspicuously convex fixigenae. A very short and transverse pygidium distinguishes $P$. chlupaci from $P$. torifrons and $P$. henkli sp. nov. Less convex and less tapering glabella with shallow glabellar furrows distinguish $P$. chlupaci from $P$. henkli. Some morphological features, such as the librigenal spines and the thorax, are unknown in P. torifrons and cannot be used in the discrimination of other species.

The first report of Ptychoparioides in the Jince area was published by Kordule (1996). Ptychoparioides chlupaci sp. nov. could be a descendent of $P$. torifrons from the Skryje-Týřovice based on some common morphological features, for example short transverse pygidium with narrow (tr.) axis.

Occurrence. - Jince area; Jince Formation, lower and middle parts of the Eccaparadoxides pusillus Zone, (Litavkaspis rejkovicensis and Acadolenus snajdri Subzones); localities Potůček and Ve žlutých near Rejkovice.

\section{Synecology of the ptychopariid trilobites in the Skryje-Týrovice area}

In the Skryje-Týrrovice area, the ptychopariid trilobites occur in various lithofacies that likely reflect diverse palaeobathymetric conditions. The diverse palaeobathymetry of recent fossil-bearing sites in the Skryje-Týřovice area was already suggested by Havlíček (1971) and Kukal (1971). In the Jince area, the ptychopariids occur in a lithofacially less varied succession with a presumably less steep sea-floor gradient. However, in contrary to taxonomic studies, little attention has been given to taphonomy and palaeoecology of the fossils assemblages in both areas. There are reports on brachiopods (Mergl \& Šlehoferová 1989), miomerid trilobites (Kordule 1996), generalised models (Fatka 1998, 2000) and trophic models or analysis of some special groups (Lefebvre \& Fatka 2003, Fatka 2005).

The important topic is to determine how indigenous are the fossil assemblages. The model presented here is based on lithological, palaeoecological and taphonomical criteria compiled from numerous sites in the Skryje-Týřovice area. In is worth to note, that part of the fossils collected in the area in last two centuries derived from heterofacial intercalations with drifted and probably mixed or sorted bioclasts. Some heterofacial fossil intercalations have lithology of distal storm-generated beds with size-sorted lithoclasts and bioclast, or show signs of rapid deposition and burial of dead animals (e.g., Pod trním locality). In almost all such sites the ptychopariids are present and are often a significant component of fossil assemblages. Four depth-related, level-bottom benthic associations could be recognized here.

The ptychopariid-mollusc association is characterised by species that lived in deeper littoral to shallow sublitoral. Among the trilobites, the dominance of ptychopariids and ellipsocephalids is characteristic. Helcionellid molluscs are fairly common, but the most numerous benthic animals in this low-diversity were fixo-sessile orthid (Pompeckium) and protorthid (Jamesella) brachiopods. Ptychoparia striata, Ptychoparioides torifrons, Perneraspis conifrons, Germaropyge cf. germari, and the brachiopod Pompeckium kuthani, are the characteristic fossils of the stratigraphically oldest known assemblage of the Skryje-Týřovice area. Most of the taxa are unknown in younger sedimentary succession in the area. Na Kamenných hưrkách and Hlohovice localities are the typical sites with the association.

The ptychoparid-ellipsocephalid association includes species of shallow inner sublittoral zone. The ptychoparids and ellipsocephalids are dominant. These groups are associated with other trilobites, mainly Lobocephalina, Skreiaspis, Conocoryphe, Ctenocephalus and Acadoparadoxides, and locally with the orthid brachiopod Bohemiella.

This association possesses the highest taxonomic diversity and is the most spatially and stratigraphically widespread association in the Skryje-Týřovice area. Ptychoparia dubinka, Mikaparia mutica, together with Germaropyge germari, Eccaparadoxides pusillus and Ptychoparioides henkli belong to the index species of the lower and middle part of the Eccaparadoxides pusillus Zone in the Skryje-Týřovice area. The Dubinky Hill locality is the typical site with the association.

The paradoxid-solenopleurid association includes species living in a moderately deep sublittoral zone. Some eurytopic species penetrate shoreward into the ptychopariid-ellipsocephalid association, and in rare cases, some elements spread more basinward into the agnostidparadoxid association. The paradoxid-solenopleurid association includes some paradoxid taxa (Hydrocephalus carens, Luhops exspectans, Eccaparadoxides pusillus, E. rohanovicus), a ptychopariid Mikaparia mutica, a conocoryphid (Bailiella granulata), solenopleurids and other trilobites (Solenopleurina tyrovicensis, Sao hirsuta, Agraulos ceticephalus), and rarely some, depth-related miomerid trilobites (Phalagnostus, Peronopsis, Condylopyge). Luh and Plazy localities are the typical sites of the association.

The agnostid-paradoxid association includes species occupying outer sublittoral zone. Agnostoid trilobites are dominant. Whether associated polymerid trilobites ( $\mathrm{Ag}$ - 


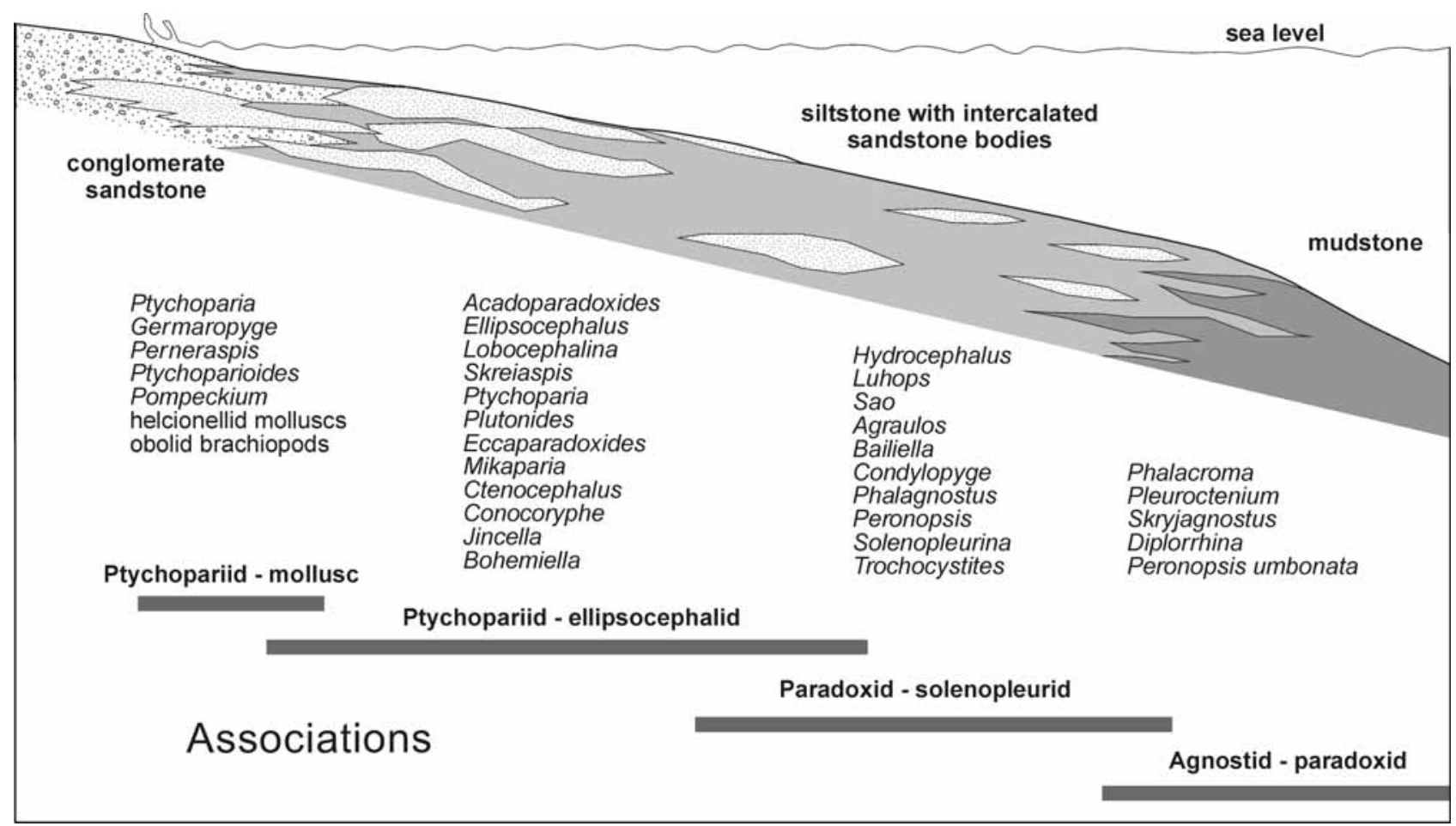

Figure 10. Diagrammatic section showing the bathymetric range of the benthic associations in the Skryje-Týřovice area and their genera.

raulos ceticephalus, Sao hirsuta, Solenopleurina tyrovicensis and an uncommon Hydrocephalus carens) are autochthonous has not been definitely solved. The Pod hruškou locality and upper part of the Luh locality area represent the typical sites for this association.

Spatial distributions of trilobites and lithofacies development imply that ptychopariid (s.s.) mostly preferred very shallow-water to shallow sublittoral environment with firm sand and silt on sea floor. This is evident from early occurrences of Ptychoparia striata and Ptychoparioides torifrons in the Mileč Formation. The species Ptychoparia sp. A is similarly known only from siltstones of the Jince area.

The assumption of a shallow sublittoral habitat of ptychopariids is supported by the abundant occurrence of Ptychoparia dubinka associated with Germaropyge germari in heterofacial sandstone lens at the Pod trním locality near Týřovice. Extensive intercalation of sand with abundant complete trilobite specimens (Ptychoparia, Germaropyge) inside mudstone succession can be explained by a slumping of unconsolidated sand from shoals into slightly deeper environment. Apparent rapid killing of the trilobite individuals happened by their deep burial in unconsolidated sand and, possibly, by dysaeroby of surrounding deeper environment. The instant burial of the trilobites in sand is indicated by completeness of exoskeletons with hypostoma in place, enrollment of the specimens, and traces of unsclerotised parts. Other ptychopariid taxa ( $M i$ kaparia) probably preferred a slightly deeper and calm environment in shallow sublittoral zone.

\section{Occurrence of ptychopariids in the Skryje-Týrrovice and Jince areas}

Pre-Ordovician erosion and the incomplete stratigraphy of the Middle Cambrian marine successions in central Bohemia makes any assumption about faunal interchange with other regions highly speculative. Havlíček (1971) originally suggested that marine transgression came to the Skryje-Týrrovice area from the Jince area. Subsequently, the same author (Havlíček 1980, 1992, 1998) suggested faunal immigration from Bavaria (Frankenwald), following the path of the suggested Middle Cambrian seaway over the Skryje-Týřovice area to the Jince area.

Representatives of Ptychoparia and Ptychoparioides are present as separate taxa in the Skryje-Týřovice area in the very beginning of the marine transgression. Mikaparia appeared slightly later.

There is diachroneity of the earliest occurrences of Ptychoparia and Mikaparia in the Skryje-Týrovice and Jince areas. In the Jince area the FAD of Mikaparia milena is in the lower part of the Eccaparadoxides pusillus Zone, and the species continues, without any distinct morphological change, into the Paradoxides gracilis Zone (Fig. 12). Its is probable, that the morphologically similar species Mikaparia mutica, restricted to the Skryje-Týřovice area, is derived from the stratigraphically earliest population of M. milena, because Mikaparia is unknown in the lower part of the Eccaparadoxids pusillus Zone in Skryje-Týrrovice area. In the same manner as M. milena in the Jince area, 


\begin{tabular}{|l|c|c|c|c}
\hline \multicolumn{1}{|c|}{ Trilobite species } & $\begin{array}{c}\text { Pt-M } \\
\text { Ass. }\end{array}$ & $\begin{array}{c}\text { Pt-E } \\
\text { Ass. }\end{array}$ & $\begin{array}{c}\text { Pa-S } \\
\text { Ass. }\end{array}$ & $\begin{array}{c}\text { A-Pa } \\
\text { Ass. }\end{array}$ \\
\hline $\begin{array}{l}\text { Agraulopsis resseri } \\
\text { Perneraspis conifrons } \\
\text { Ptychoparia striata } \\
\text { Ptychoparioides torifrons } \\
\text { Lobocephalina emmrichi } \\
\text { Germaropyge germari } \\
\text { Ellipsocephalus cf. hoffi } \\
\text { Ptychoparia dubinka }\end{array}$ & - & & & \\
Mikaparia mutica & & & & \\
Ptychoparioides henkli \\
Ctenocephalus coronatus \\
Skreiaspis spinosa \\
Acadoparadoxides cf. sirokyi \\
Plutonides kozaki \\
Eccaparadoxides pusillus \\
Eccaparad. rohanovicus \\
Luhops expectans \\
Hydrocephalus carens \\
Conocoryphidae (s.s.) \\
Bailiella granulata \\
Solenopleura sp. \\
Jincella prantli
\end{tabular}

Figure 11. Distribution of trilobites in the benthic associations of the Skryje-Týrovice area. Pt-M Ass. - ptychopariid-mollusc association, Pt-E Ass. - ptychopariid-ellipsocephalid association, Pa-S Ass. - paradoxid-solenopleurid association, A-Pa Ass. - agnostid-paradoxid association.

also Mikaparia mutica pass over the upper limit of the Eccaparadoxides pusillus Zone in the Skryje-Týřovice area.

Ptychoparia striata is the characteristic ptychopariid of the Eccaparadoxides pusillus to Paradoxides gracilis zones in the Jince area (Fig. 12). Outside the Jince area, it is known in the Mileč Formation and in the lowest succession of the Jince Formation of the Skryje-Týrovice area (Týřovice Conglomerate and Greywackes below the Eccaparadoxides pusillus Zone) (Figs 12, 13). Higher in the succession in the Skryje-Týřrovice area, $P$. striata is substituted by the closely related $P$. dubinka, which disappears in the upper part of the Eccaparadoxides pusillus Zone (Figs 12, 13). Unlike $P$. striata, the species $P$. dubinka is unknown in the Jince area.

Additional differences between the Skryje-Týrovice and Jince areas include the particular species of Ptychopa- rioides ( $P$. torifrons, $P$. henkli in the Skryje-Týrovice area and $P$. chlupaci in the Jince area) present in successions of approximately same age (lower part of the Eccaparadoxides pusillus Zone or older zones.

Despite general similarity of the benthic marine biota of the Jince and Skryje-Týřovice areas, there are striking taxonomic differences in their ptychopariid trilobite associations. This difference, together with occurrence of particular taxa restricted to one of the two areas (e.g., in brachiopods), indicates remarkably independent evolution of marine communities in both the areas, despite their geographical proximity at the present time. This is consistent with existence of a palaeogeographic barrier that restricted interchange of marine biota.

\section{Stratigraphy - a review}

Although the total thickness of the Cambrian sediments in the Skryje-Týřovice area attains some $200 \mathrm{~m}$ (Havlíček 1998), a finer biostratigraphical subdivision of these beds has not been undertaken. This is due in part to the deformation and erosion of the Middle Cambrian sediments towards the SW, and the scantiness of exposures of the Mileč and Jince formations, especially at their boundary interval. Another difficulty is the accurate correlation of particular localities because of uneven lithofacies development and presence of various faunal assemblages.

A review of the different approaches taken in studying the stratigraphy of the Skryje-Týřovice area since 1884 was given by Šnajdr (1958, pp. 19-21). The most valuable information were presented in articles of Jahn (1896) and Kettner (1923). There are a few additional stratigraphical reports on the area. Jarka (1940) published a list of species from various stratigraphical levels of the Skryje Shale at the slope Dlouhá hora near Skryje. This author attempted to correlate the ranges of these taxa with those from the Jince area. He did not subdivide the Skryje Shale, but reported restriction of Sao hirsuta and Solenopleura tyrovicensis to the upper part of the succession. Pribyl \& Jarka (1946, p. 289) applied data from Jarka (1940), with a brief note that the beds with Sao hirsuta constitute a biostratigraphical horizon.

Prantl (1947) took notice of a horizon with Sao hirsuta, Pleuroctenium granulatum and Solenopleura tyrovicensis in the upper part of the Skryje Shale without any detailed definitions. He suggested that this horizon is overlain by horizon with Ceratocystis perneri and Lobocephalina emmrichi. However, these species have a longer stratigraphical span and are present below the Sao hirsuta horizon.

Šnajdr (1958) incorporated all fossiliferous levels into the Eccaparadoxides pusillus Zone due the presence of paradoxid trilobites in the basal sandstones of the Mileč 


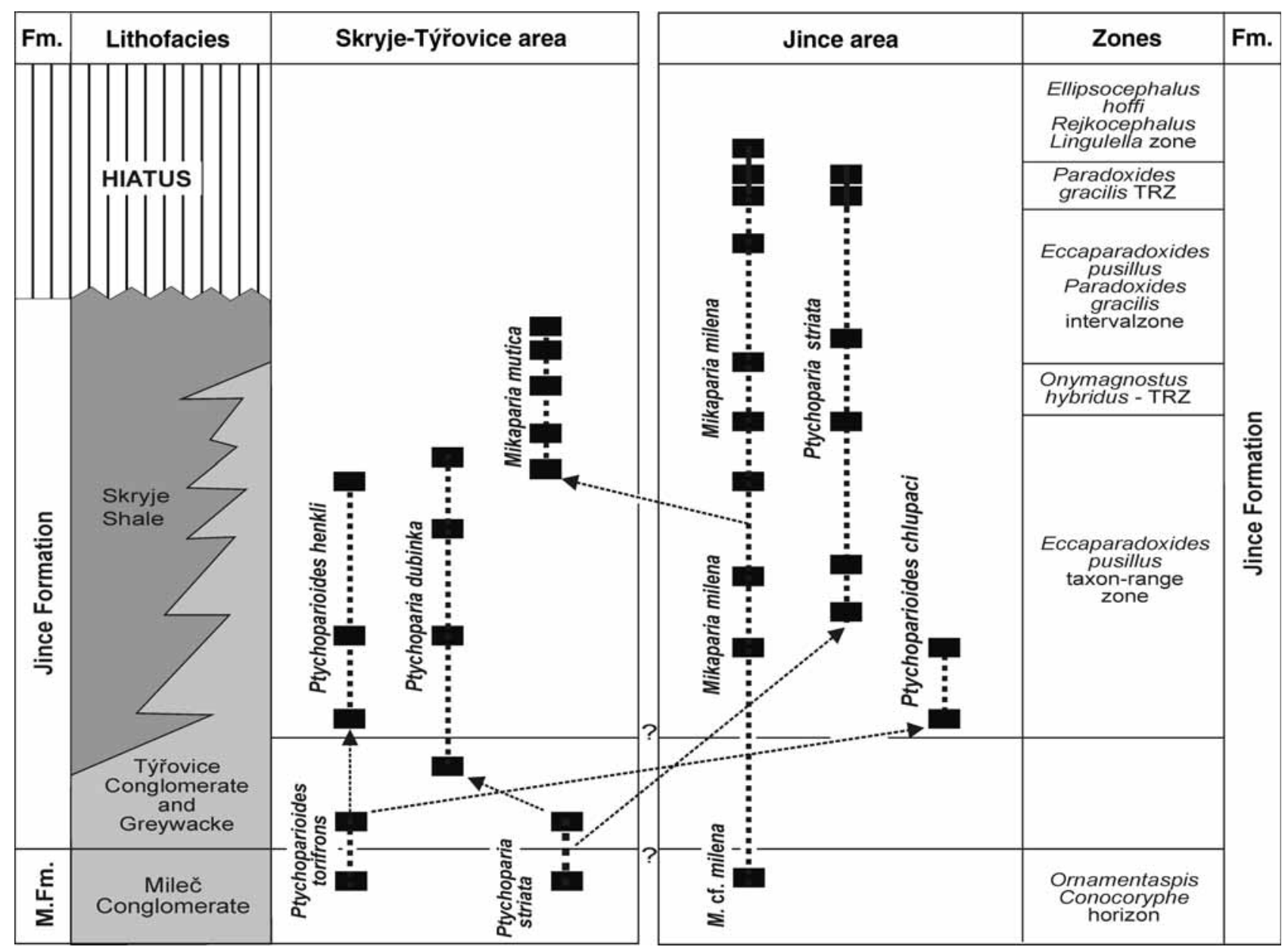

Figure 12. Ranges of particular ptychopariid trilobites in the Skryje-Týřovice area and Jince area. Stratigraphy modified after Kordule (1996) and Fatka et al. (2004). Abbreviations: TRZ - taxon-range zone, M.Fm. - Mileč Formation.

Formation. However, among the paradoxid remains in the Mileč Formation, the presence of Eccaparadoxides has not been proved yet; the fragments of skeletons belong to another genus, probably Hydrocephalus. Havlíček (1971) presented a different approach; this author defined two brachiopod zones in the Skryje-Týřovice area. The older is characterised by Pompeckium kuthani and the younger by Bohemiella romingeri. The latter species is restricted to the Skryje Shale facies only. The range of the older zone includes the Mileč Conglomerate and Sandstone and the lower part of the Týřovice Greywacke (Havlíček 1971). The Týrovice Greywacke extends into the upper half of the Jince Formation, and thus overlaps the upper part of the Eccaparadoxides pusillus Zone of the clayey lithofacies. In Havlíček's original concept (1971), the Mileč Sandstone and Conglomerate is only a local stratigraphical unit, absent in other parts of the basin. Based on his opinion, the younger Týrovice Greywacke and Skryje Shale should directly cover the Proterozoic bedrocks at some sites, especially in the NE part of the basin (Havlíček 1971, p. 41, fig. 4). However, this concept contradicts with finds of fossiliferous conglomerate and sandstone that has been made by M. Szabad and the present author at Malá Pleš in 1996, in the NE extremity of the preserved Cambrian sediments of the Skryje-Týřovice area. The Czech Stratigraphic Subcommission incorporated the Mileč Conglomerates and Sandstones into the Mileč Formation (Havlíček in Klomínský 1994).

The Eccaparadoxides pusillus Range Zone in the Skryje-Týřovice area was subsequently defined with a new Acadoparadoxides cf. sirokyi Subzone. The index species of the youngest preserved beds of the Eccaparadoxides pusillus Range Zone in the Skryje-Týřovice area were listed by Kordule (1999). This fauna includes Mikaparia mutica, Sao hirsuta, Plutonides kozaki, Agraulos ceticephalus and some agnostids (e.g., Condylopyge rex, Diplorrhina cuneifera, Peronopsis umbonata).

Kettner (1923, pp. 17-24) named specific lithological units of the Middle Cambrian in the Skryje-Týřovice area that had been distinguished by Jahn (1896) and Kettner \& 
Kodym (1919). Kettner (1923) separated the "Orthis Sandstone" ("orthisové pískovce" in Czech) from the Mileč Sandstone and Conglomerate, and united the former with the Týrovice Conglomerate in a new unit called the Týřovice Conglomerate and Sandstone. He suggested that the fauna of the Mileč Sandstone from the Na Kamenných hưrkách and Mileč Hill localities is older than fauna of the "Orthis Sandstone" from the Luh, Slapnický mlýn, and Lohovice localities. Růžička (1940, p. 11) revised the trilobite fauna from the basal sandstone of the Mileč Sandstone, and observed that it is undistinguishable from that of the "Orthis Sandstone" in Skryje and Lohovice. He suggested the same faunal age for both units. New observations by the present author in Hlohovice and outcrops in the Zbiroh Creek valley support the opinion of Růžička (1940). For instance, the trilobite Perneraspis conifrons, which was hitherto known from the Mileč Conglomerate and Sandstone, has now been found in the Týrovice Conglomerate and Greywacke at Hlohovice and the new locality U tří chat near Čilá. This species might be useful as an index species for the Perneraspis conifrons Range Zone, but the definition of such a zone is premature at present.

\section{New proposal of biostratigraphic zonation in the Skryje-Týřovice area}

Summarizing the available data (including new investigations of time and space distributions of ptychoparid trilobites), the new proposal of biostratigraphical zonation based on assemblage zones and barren intervals is suggested for the Mileč and Jince formations (in ascending order; Fig. 11):

a) Barren interval in the lower part of the Mileč Formation (oldest Cambrian sediment in the area);

b) Ptychoparia striata Assemblage Zone containing the index species Ptychoparia striata, Perneraspis conifrons, Ptychoparioides torifrons.

c) Barren interval in the lower part of the Jince Formation, from the top of the preceding zone to the lower boundary of the Acadoparadoxides cf. sirokyi Abundance Zone.

d) Acadoparadoxides cf. sirokyi Abundance Zone.

e) Ptychoparia dubinka Assemblage Zone, containing the index species Ptychoparia dubinka, Germaropyge germari, Ptychoparioides henkli, and Eccaparadoxides pusillus.

f) Mikaparia mutica Assemblage Zone, containing the index species Mikaparia mutica, Sao hirsuta, Agraulos ceticephalus, Jincella prantli, Diplorrhina cuneifera, Condylopyge rex, Peronopsis umbonata, and Phalagnostus nudus.

g) Barren interval in the uppermost part of the Jince Formation.

\section{Ptychoparia striata Assemblage Zone}

The Ptychoparia striata Assemblage Zone is known in the Mileč Formation, but it extends to lower part of the Týrovice Conglomerate and Greywacke. The Týřovice Conglomerate and Greywacke have been referred to the Jince Formation (Havlíček 1971, Havlíček in Klomínský 1994) and are mainly present in the lower part the formation. Total estimated thickness of the zone is 8 to $20 \mathrm{~m}$.

\section{Acadoparodoxides cf. sirokyi Abundance Zone}

The index species Eccaparadoxides pusillus is rare in the lowest beds referred to the Eccaparadoxides pusillus Taxon Range Zone. This led Kordule (1999) to definition of this interval as the Acadoparadoxides cf. sirokyi Taxon Range Zone. The zone includes about $10 \mathrm{~m}$ thick interval exposed on the slope of Dubinky Hill, which is the type-locality of the zone. Apart from the index species, Ellipsocephalus cf. hoffi is rarely present. At this site, the highest part of the zone yielded one cranidium of Eccaparadoxides pusillus.

A more diversified assemblage is known at a locality near the Hlaváč's village near the Podmokelský mlýn locality (Kordule 1999). Associated with Acadoparadoxides cf. sirokyi, the trilobites Ptychoparia dubinka, Lobocephalina emmrichi, Ptychoparioides henkli, Ellipsocephalus cf. hoffi, Peronopsis sp. and an orthid Bohemiella romingeri were collected there. However, the index species Eccaparadoxides pusillus is absent. This difference may be explained by the heterochrony of the lower boundary of the Acadoparadoxides cf. sirokyi and the Eccaparadoxides pusillus zones. It appears likely that Acadoparadoxides cf. sirokyi should be found even in older beds than is currently known; therefore, the succession with Acadoparadoxides cf. sirokyi is renamed to the Acadoparadoxides cf. sirokyi Abundance Zone. Total estimated thickness is about $10 \mathrm{~m}$.

\section{Ptychoparia dubinka Assemblage Zone}

The beds overlying the Acadoparadoxides cf. sirokyi Abundance Zone are rich in fossils, and the succession is defined as the Ptychoparia dubinka Assemblage Zone. This zone is defined by the presence of Ptychoparia dubinka, Germaropyge germari, Ptychoparioides henkli, and Eccaparadoxides pusillus. The zone contains a more diversified association, with Ptychoparia dubinka, Lobocephalina emmrichi, Conocoryphe sulzeri atlanta, Ellipsocephalus cf. hoffi, Skreiaspis spinosa, Eccaparadoxides pusillus, and an orthid Bohemiella romingeri. The trilobites Germaropyge germari, Hydrocephalus carens, 


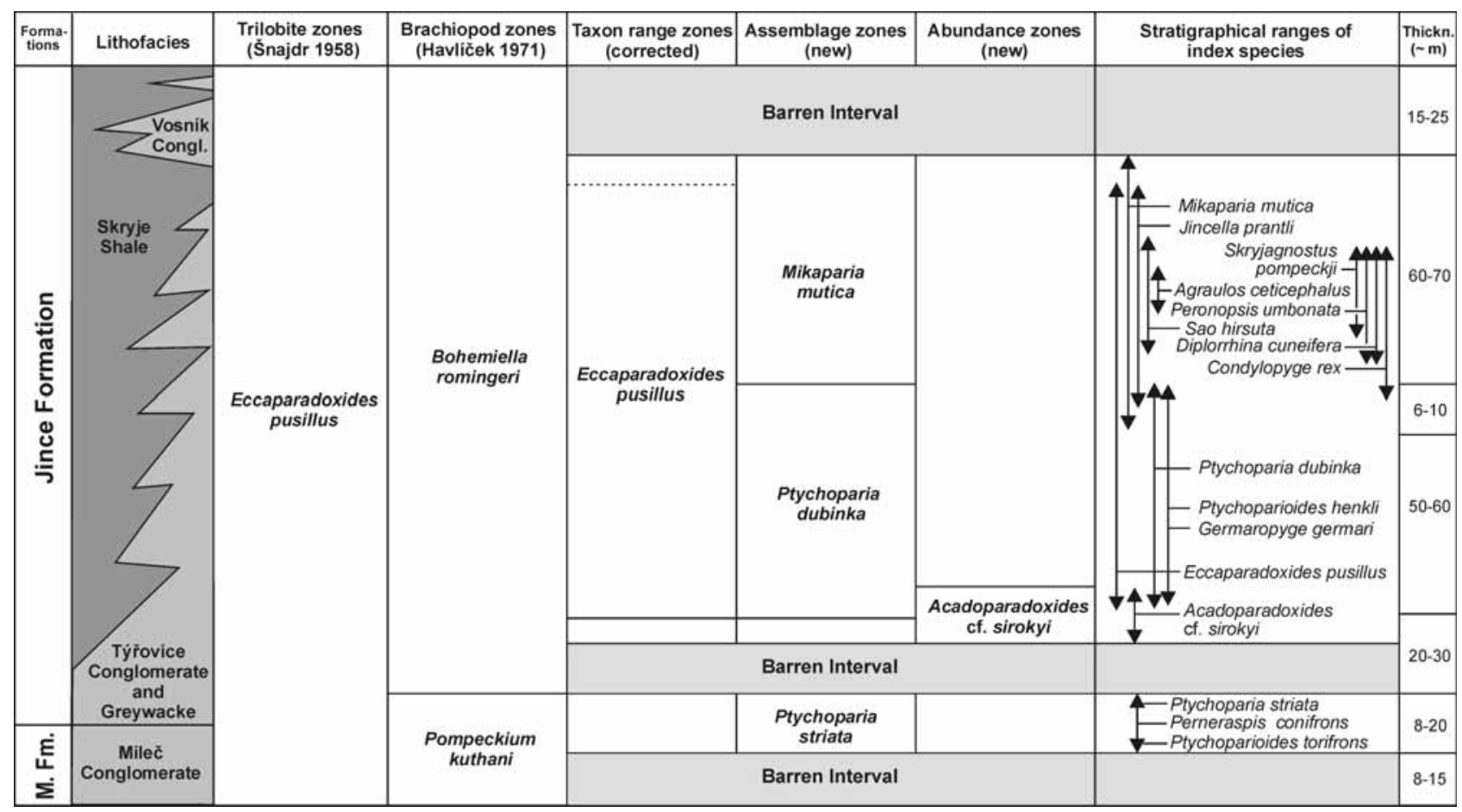

Figure 13. Correlation of the biostratigraphy of the Middle Cambrian in the Skryje-Týřrovice area after Šnajdr (1958), Havlíček (1971), corrected ranges of taxon-range and abundance zones, newly defined assemblage zones, and ranges of the index species. Abbreviations: M.Fm. - Mileč Formation.

Ctenocephalus coronatus, and Peronopsis cf. integer are less common. The rare trilobites are Ptychoparioides henkli, Luhops expectans, Parabailiella granulata, and Peronopsis umbonata (Jarka's collection, exact level unknown). Hyolithids are generally less common. Lichenoides, Stromatocystites, Ceratocystis, and Etoctenocystis represent echinoderms. The typical occurrence of the Ptychoparia dubinka Assemblage Zone is in the middle part of the slope of Dlouhá hora and Dubinky Hill near Skryje (Kordule 1999). Other known occurrences of this zone are situated at the NE slope of Karáskova rokle (Pod trním locality), in the NW slope of the Buchava locality, at Čihátko Hill, and Biskoupky. Total estimated thickness of the zone is $60 \mathrm{~m}$.

\section{Mikaparia mutica Assemblage Zone}

The Ptychoparia dubinka Assemblage Zone is substituted by the Mikaparia mutica Assemblage Zone approximately in the middle part of the Skryje Shale. The base of the Mikaparia mutica Assemblage Zone is defined by the last occurrence of the species Ptychoparia dubinka. The co-occurrence of $P$. dubinka and $M$. mutica is known from the approximately $8 \mathrm{~m}$ thick succession at the top of the Ptychoparia dubinka Assemblage Zone. The Mikaparia mutica Assemblage Zone occupies a nearly $60 \mathrm{~m}$ thick succession, and is characterized by a rich association of po- lymerid and miomerid trilobites. This zone is also characterised by occurrence of Sao hirsuta, Agraulos ceticephalus, Jincella prantli, Diplorrhina cuneifera, Condylopyge rex, Peronopsis umbonata, and Phalagnostus nudus. Trilobites Solenopleura tyrovicensis, Conocoryphe sulzeri cirina, Conocoryphe sulzeri atlanta, and Bailiella granulata are less common. The paradoxid Hydrocephalus carens is very frequent, while Eccaparadoxides pusillus is restricted to the lower two-thirds of the zone. Less frequent are $E c$ caparadoxides rohanovicus, Jincella prantli, Skreiaspis spinosa, Ellipsocephalus aff. hoffi, and Ctenocephalus coronatus. Species Plutonides kozaki, Luhops expectans, Germaropyge germari, and Solenopleura sp. nov. are rare.

The suggested deepest part of the basin near Týrovice and Skryje (Kukal 1971) yielded common agnostoids. Some of them are important for local biostratigraphical subdivision as well as for extrabasinal correlations. In this, probably the deepest part of the basin, their abundant occurrence indicates the base of the Mikaparia mutica Assemblage Zone, while in sites only some $2 \mathrm{~km}$ toward the $\mathrm{SW}$, the base is defined by the index species Mikaparia mutica. The miomerid trilobites are represented by Diplorrhina cuneifera, Phalagnostus nudus, Condylopyge rex, Phalacroma bibullatum, Skryjagnostus pompeckji, Peronopsis umbonata, Pleuroctenium granulatum, and Peronopsis cf. integra. Echinoderms are represented by the abundant Trochocystis bohemica, while Trochocystoides parvus, Etoctenocystis cf. bohemica, Luhocrinus monicae, 
and Ceratocystis perneri are rare. Brachiopods are represented by small and generally rare species of Lingulella and Luhotreta, and also by the orthid Bohemiella romingeri in more shoreward sites of the basin. Hyoliths are represented by several species. Helcionellids are rare, and Volborthella has been found.

The range of the Mikaparia mutica Assemblage Zone continues above the upper limit of the Eccaparadoxides pusillus Range Zone. Stratigraphical ranges of particular species of the Mikaparia mutica Assemblage Zone are different. Mikaparia mutica, Jincella prantli, and Ctenocephalus coronatus are known from the entire range of the zone (about $60 \mathrm{~m}$ in thickness). The ranges of other species are more restricted. Sao hirsuta is known from an approximately $40 \mathrm{~m}$ thick succession in the middle of the zone. Agraulos ceticephalus occurs only in the middle part of the zone, in cca $10 \mathrm{~m}$ thick succession. In addition, a poorly outcropping Skryje Shale and strong tectonic deformation locally obscure their actual ranges.

The Mikaparia mutica Assemblage Zone is the best-known zone of the Cambrian sequence in the Skryje-Týřovice area. The type area with passage of the Ptychoparia dubinka Assemblage Zone to the Mikaparia mutica Assemblage Zone is on the wooded slope close to Podmokelský mlýn. The adjacent lowest succession of Mikaparia mutica Assemblage Zone is in adjacent Buchava Quarry.

Numerous historical collecting sites lie within this zone. The zone is known at more localities: Studená hora Hill, a gorge near Týřovice, Lůmek near Týřovice, Pod hruškou locality, an opening of Karáskova rokle, Luh, Plazy, Skryje village, upper outcrops at slope of Dlouhá hora and Dubinky Hill. Approximate total thickness of the zone is $70 \mathrm{~m}$.

\section{Barren intervals}

Some parts of the Middle Cambrian succession in the Skryje-Týřovice area did not yield any fossils; these sucessions are defined as barren intervals. Kordule (1996) suggested that the succession in the upper part of the Týrovice Conglomerate and Greywacke and the lower part of the Skryje Shale (about $40 \mathrm{~m}$ ) are unfossiliferous, but new data indicate that the Barren Interval (Kordule 1996) has thickness of 20-30 m. This barren interval is developed as alternation of thin layers of greywackes (Týrovice Conglomerate and Greywacke) and mudstones (Skryje Shale).

\section{Conclusions}

Numerous localities in the Skryje-Týřovice area and their fauna have been studied since the mid-nineteen century
(Jahn 1896; Kettner 1923; Jarka 1940; Růžičcka 1940; Prantl 1941, 1947; Přibyl \& Jarka 1946; Chlupáč et al. 1998; Vokáč 1997 etc.). However, many localities in the same area were overlooked. The Dubinky Hill locality should be noted as an example (Kordule 1999). It had never been studied before, although its significance for stratigraphy and the taxonomy of ptychopariids is outstanding. These exposures on the steep slope of the Zbirožský Creek valley constitute the most complete sequence of the Skryje Shale, with basinward, deepening trends in the succession. A weak tilting and faulting, good outcropping, and rich fossil content are other advantages of this sequence, so that this section currently represents one of the most significant sections of the Jince Formation in the Skryje-Týrovice area.

New data about spatial and stratigraphical distribution of ptychopariid trilobites allow to propose a bathymetrical model for the benthic, trilobite-dominated associations in the Skryje-Týřovice area. A new proposal of biostratigraphical subdivisions of the Mileč and Jince formations is presented with three new assemblage zones: Ptychoparia striata Assemblage Zone, Ptychoparia dubinka Assemblage Zone, and Mikaparia mutica Assemblage Zone. Stratigraphical ranges of index taxa are plotted (Fig. 13). There are striking differences in the taxonomic composition of ptychopariids, other trilobites, as well as the invertebrates (see review of Havlíček 1998, Fatka et al. 2004) in fossils assemblages between the Jince and Skryje-Týřovice areas, and also in the stratigraphical ranges of particular ptychoparioid species. This difference indicates palaeogeographic separation of both areas in the Middle Cambrian.

\section{Acknowledgements}

The author is grateful to all persons that helped with this work, above all to late I. Chlupáč, G. Geyer (Institute of Palaeontology, University of Würzburg), N. Hughes (Department of Earth Sciences, University of California), O. Fatka (Institute of Geology and Palaeontology, Charles University, Prague), and P. Budil (Czech Geological Survey, Prague) for valuable critical revisions and comments on the manuscript, to M. Mergl (University of West Bohemia, Plzeň) and R. Šarič (Czech Geological Survey, Prague) for technical help. The author also wishes to express thanks for specimens loaning by F. Knížek, L. Mandík, L. Henkl, V. Kozák, and J. Gardavský.

\section{References}

BARRANDE, J. 1852. Système silurien du centre de la Bohême. İ̀re partie: Recherches paleontologiques. I. Crustacés. Trilobites. Praha, Paris.

CHLuPÁČ, I. 1993. Geology of the Barrandian. A field trip guide. Senckenberg-Buch 69. Frankfurt am Main. 
Chlupáč, I., Fatka, O., Prokop, R.J. \& Turek, V. 1998. Výzkum klasické paleontologické lokality „Luh“ ve skryjském kambriu. Journal of the Czech Geological Society 43(3), 169-173.

ChlupÁč, I., HavlíčeK, V., KŘíž, J., Kukal, Z. \& ŠTorch, P. 1992. Paleozoikum Barrandienu (kambrium-devon). 292 pp. Ústřední ústav geologický, Praha.

EMMrich, H.F. 1839. De trilobitis. Dissertatio petrefactologica. Berolini.

FATKA, O. 1998. Paleontologická naleziště v brdském kambriu: nutnost ochrany, 67-72. In CíleK, V. (ed.) Př́roda Brd, Publication OÚ Př́ibram.

FAtKA, O. 2000. Das Mittlere Kambrium bei Jince, Tschechische Republik, 21-23, 49-50, 244. In PinNA, G. \& MEISChNER, D. (eds) Europäische Fossillagerstäten. Springer.

FATKA, O. 2005. Geologická stavba, 30-44. In CíleK, V. (ed.) Středni Brdy. MZe ČR, MŽP ČR, ČSOP Příbram a Kancelár pro otázky ochrany přírody a krajiny Příbram, Příbram.

FATKA, O. 2006. Biostratigraphy of the Jince Formation (Middle Cambrian) in the Př́bram-Jince Basin: Historical review. Acta Universitatis Carolinae, Geologica, 47(1-4), 53-61.

FAtKA, O. \& Kordule, V. 1992. New fossil sites in the Jince Formation. Věstník Českého geologického ústavu 67(1), 47-60.

FAtKA, O., Kordule, V. \& SzABAD, M. 2004. Stratigraphical distribution of Cambrian fossils in the Příbram-Jince Basin (Barrandian area, Czech Republic). Senckenbergiana lethaea 84(1/2), 367-389.

HAVLÍČEK, V. 1971. Stratigraphy of the Cambrian of Central Bohemia. Sborník geologických věd, Geologie 20, 7-52.

HAVLÍČEK, V. 1980. Development of Palaeozoic basins in the Bohemian Massif (Cambrian-Lower Carboniferous). Sborník geologických věd, Geologie 34, 31-65.

HAVLÍČEK, V. 1992. Příbramsko-jinecká pánev, 28-55. In CHLUPÁČ, I., HaVlíčeK, V., KŘíž, J., KuKal, Z. \& ŠTorCh, P. Paleozoikum Barrandienu (kambrium-devon). Ústřední ústav geologický, Praha.

HAVlíČEK, V. 1994. 13. Cambrian. In KLOMínskÝ, J. (ed.) Geological Atlas of the Czech Republic, Stratigraphy. Czech Geological Survey, Praha.

HavlíčEK, V. 1998. Cambrian, 20-38. In ChlupáČ, I., HavlíČEK, V., Kříž, J., KuKAL, Z. \& ŠTORCH, P. Palaeozoic of the Barrandian. Czech Geological Survey, Praha.

HAwle, I. \& CoRDA, A.J.C. 1847. Prodrom einer Monographie der böhmischen Trilobiten. Abhanglungen Köningliche Böhmische Gesseschaft für Wissenschaft 5, 117-292.

Henningsmoen, G. 1952. Early Middle Cambrian Fauna from Rogaland, SW Norway. Norsk geologisk Tidskrift 30, 13-32.

HORNÝ, R. \& BASTL, F. 1970. Type specimens of fossils in the National Museum Prague. Trilobita. Vol. 1. 354 pp. Národní muzeum, Praha.

Hupé, P. 1955. Classification des Trilobites. Annales de Paléontologie 41, 91-325.

JAEKEL, O. 1901. Beitrage zur Beurteilung der Trilobiten. Th. I. Zeitschrift der deutsche geologische Gesseschaft 53(1), 133-171.

JAHN, J.J. 1896. Uber die geologischen Verhaltnisse des Kambrium von Tejřovitz und Skrej in Böhmen. Jahrbuch der Keiserischen-köninglinchen geologischen Reichanstalt 45, 641-790.
JARKA, J. 1940. Příspěvek k poznání stratigrafie skryjských břidlic cß’2. Věstník Královské české společnosti nauk, 1-17.

KAFKA, J. \& PERneR, J. 1907. Výlet do českého kambria. Vesmir 36, 276-277, 291-293.

KeTtNER, R. 1923. Kambrium skrejsko-tejřovické a jeho okolí. Sborník Státního geologického ústavu Československé republiky 3, 1-63.

KETTNER, R. 1946. Některé problémy českého algonika a kambria. Sborník Státního geologického ústavu Československé republiky 13, 41-67.

KeTtNeR, R. \& Kodym, O. 1919. Nová stratigrafie Barrandienu. Časopis Musea Království českého 93, 48-57.

KLOMínskÝ, J. (ed.) 1994. Geological Atlas of the Czech Republic, Stratigraphy. 17 pp. Czech Geological Survey, Praha.

Kordule, V. 1996. Importance of some less known fossiliferous localities for the stratigraphy of the Jince Formation in the Bohemian Middle Cambrian. Věstník Českého geologického ústavu 71(1), 37-49.

Kordule, V. 1999. New data about paradoxid trilobites from Middle Cambrian of Central Bohemia. Věstník Českého geologického ústavu 74(1), 17-25.

KuKAL, Z. 1971. Sedimentology of Cambrian deposits of the Barrandian area (Central Bohemia). Sborník geologických věd, Geologie 20, 53-100.

LEFEBVRE, B. \& FATKA, O. 2003. Palaeogeographical and palaeoecological aspects of the Cambro-Ordovician radiation of echinoderms in Gondwannan Africa and peri-Gondwannan Europe. Palaeoceanography, Palaeoclimatology, Palaeoecology 195, 73-97.

LEVI-SETTI, R. 1993. Trilobites (second edition). 342 pp. University Chicago Press, Chicago.

LoRENZ, T. 1906. Beiträge zur Geologie und Paläontologie von Ostasien unter besonderer Berücksichtigung der Provinz Schantung in China, Th. II. Zeitschrift der Deutschen geologischen Gesseschaft 58, 1-57.

Mergl, M. \& ŠLehoferovÁ, P. 1990. Middle Cambrian inarticulate brachiopods from Central Bohemia. Sborník geologických věd, Paleontologie 31, 65-104.

Moore, R.C. 1959. Treatise on Invertebrate Paleontology. Part O, Arthropoda 1. 560 pp. Geological Society of America \& University of Kansas Press, Lawrence, Kansas \& Boulder, Colorado.

PeK, J. \& VANĚK, J. 1989. Index of Bohemian Trilobites. Krajské Muzeum Olomouc, 1-68.

POMPECKJ, J.F. 1896. Die Fauna des Cambriums von Tejřovic und Skrej in Böhmen. Jahrbuch der Geologischen Reichsanstalt 45, 495-615.

PrANTL, F. 1941. O nalezišti kambrických zkamenělin ,,pod trním“ u Skryjí. Věda přirodní 20(4), 118-120.

Prantl, F. 1947. O nalezišti zkamenělin Pod hruškou v skryjsko-týřovickém kambriu. Věstník Musejního spolku královského města Rakovníka a politického okresu rakovnického 32, 53-58.

PRANTL, F. 1952. Život českých pramoři. 390 pp. Česká akademie věd a umění v Praze, Přírodovědecké vydavatelství, Praha.

Prokop, R. 1989. Zkamenělý svět. 275 pp. Práce, Praha.

PřIBYL, A. 1953. Seznam českých trilobitových rodů. Knihovna Ústředního ústavu geologického 25, 1-80.

PŘiBYL, A. \& JARKA, J. 1946. Profil nejmladšími vrstvami skryjsko-týřovického kambria v okolí Vosníku a naleziště Pod 
hruškou. Věstník Státního geologického ústavu Československé republiky 21, 286-290.

RichteR, R. 1940. Trilobiten der ältesten kambrischen Fauna Böhmens von Tejřovitz (Kamenná Hůrka). Neues Jahrbuich für Mineralogie, Ref. III., 1033.

Richter, R. \& RichteR, E. 1941. Die Fauna des Unter-Kambriums von Cala in Andalusien. Abhandlungen Senckenbergische naturforschung Gesellschaft 455, 1-90.

RƯŽIČKA, R. 1940. Trilobiti nejstarší české kambrické fauny od Týřovic z Kamenné hůrky. Rozpravy I. třídy české akademie 49, 1-12.

RŮŽIČKA, R. 1944. O některých význačných trilobitech skryjského kambria. Věstník Královské české společnosti nauk, Tř́ida matematicko-prrírodovědecká, 1-26.

STERNBERG, K. 1825. Übersicht der in Böhmen dermalen bekannten Trilobiten. Verhandlungen der Gesselschaft des vaterländischen Museums in Böhmen, 3, Beilage B, 69-86.

ŠNAJDR, M. 1958. Trilobiti českého středního kambria. Rozpravy Ústředního ústavu geologického 24, 1-280.

ŠNAJDR, M. 1982. Bohemian representatives of the trilobite gen- era Conocoryphe Hawle-Corda and Parabailiella Thoral. $\breve{C} a-$ sopis pro mineralogii a geologii 27(1), 1-9.

ŠNAJDR, M. 1983. Revision of the trilobite type material of I. Hawle and A.J.C. Corda 1847. Sborník Národního muzea 39, $129-212$.

ŠNAJDR, M. 1986. Revize málo známých a pochybných druhů trilobitů z Barrandienu. Časopis Národního muzea, $\breve{R} a d a B$ 155(1-2), 21-29.

ŠNAJDR, M. 1990. Bohemian Trilobites. 265 pp. Czech Geological Survey, Praha.

VALÍČEK, J. \& SZABAD, M. 2002. Revision early Middle Cambrian trilobite fauna from Central Bohemia. Palaeontologia Bohemiae 8, 75-98.

VANĚK, J. \& VALÍČEK, J. 2001. New index of the genera, subgenera, and species of Barrandian trilobites. Palaeontologia Bohemiae 7(1), 1-49.

VOKÁČ, V. 1997. Middle Cambrian benthic assemblage in the Skryje Shale (Jince Formation) at Terešovská Hut (District of Rokycany, Czech Republic). Palaeontologia Bohemiae 3(6), 15-19. 